\title{
How Does Investor Confidence Lead to Trading? Linking Investor Return Experiences, Confidence, and Investment Beliefs
}

Citation for published version (APA):

Hoffmann, A., \& Post, T. (2016). How Does Investor Confidence Lead to Trading? Linking Investor Return Experiences, Confidence, and Investment Beliefs. Journal of Behavioral and Experimental Economics, 12, 65-78. https://doi.org/10.1016/j.jbef.2016.09.003

Document status and date:

Published: 01/12/2016

DOI:

10.1016/j.jbef.2016.09.003

Document Version:

Accepted author manuscript (Peer reviewed / editorial board version)

Document license:

CC BY-NC-ND

Please check the document version of this publication:

- A submitted manuscript is the version of the article upon submission and before peer-review. There can be important differences between the submitted version and the official published version of record.

People interested in the research are advised to contact the author for the final version of the publication, or visit the DOI to the publisher's website.

- The final author version and the galley proof are versions of the publication after peer review.

- The final published version features the final layout of the paper including the volume, issue and page numbers.

Link to publication

\footnotetext{
General rights rights.

- You may freely distribute the URL identifying the publication in the public portal. please follow below link for the End User Agreement:

www.umlib.nl/taverne-license

Take down policy

If you believe that this document breaches copyright please contact us at:

repository@maastrichtuniversity.nl

providing details and we will investigate your claim.
}

Copyright and moral rights for the publications made accessible in the public portal are retained by the authors and/or other copyright owners and it is a condition of accessing publications that users recognise and abide by the legal requirements associated with these

- Users may download and print one copy of any publication from the public portal for the purpose of private study or research.

- You may not further distribute the material or use it for any profit-making activity or commercial gain

If the publication is distributed under the terms of Article $25 \mathrm{fa}$ of the Dutch Copyright Act, indicated by the "Taverne" license above, 


\title{
How Does Investor Confidence Lead to Trading? Linking Investor Return Experiences, Confidence, and Investment Beliefs
}

\author{
Arvid O. I. Hoffmann* \\ Maastricht University and Netspar \\ Thomas Post \\ Maastricht University and Netspar
}

This version: May 12, 2016

\begin{abstract}
Confident investors trade more than less confident investors, but why? Prior research tests the ultimate relation between investor confidence and trading, but does not empirically examine the underlying mechanism that explains why confidence leads to trading. We complement the literature by developing a theoretical framework and presenting empirical evidence on a psychologically plausible mechanism through which confidence leads to trading. Using a combination of individual investors' brokerage records and matching monthly survey data, we show that more confident investors rely more on intuitive judgments when forming beliefs about expected returns. In particular, they rely more on naïve reinforcement learning and extrapolate individual return experiences into the future more strongly. Given the same return experience, more confident investors change their beliefs more strongly, providing more reason to trade. Ultimately, confident investors have higher turnover, which hurts their performance.
\end{abstract}

JEL Classification: D14, D81, D83, D84, G02, G11

PsycINFO: 3920

Keywords: Belief Formation, Investor Confidence, Naïve Reinforcement Learning, Return Experiences, Trading

* Corresponding author: Arvid O. I. Hoffmann, Maastricht University, School of Business and Economics, Department of Finance, P.O. Box 616, 6200 MD, The Netherlands. Tel.: +31 433884 602. E-mail: a.hoffmann@ maastrichtuniversity.nl.

This research would not have been possible without the help of a large brokerage firm. The authors thank this broker and its employees. For their comments on earlier drafts of this paper, the authors thank Clifton Green, Adam Greenberg, Zwetelina Iliewa, Lena Jaroszek, Robin Lumsdaine, Christoph Merkle, Sebastien Pouget, Nicolas Salamanca, Stephan Siegel, Oliver Spalt, and seminar and conference participants at the University of British Columbia, the University of Washington, Maastricht University, the MiSoC Workshop on Subjective Expectations and Probabilities in Economics and Psychology at the University of Essex, the 13th Colloquium on Financial Markets, the Boulder Summer Conference on Consumer Financial Decision Making, Goethe-University Frankfurt, Aalto University, the TIBER Symposium on Psychology and Economics, the Research in Behavioural Finance Conference at Erasmus University, the Centre for European Economic Research (ZEW), Mannheim University, Leeds University, the University of Southampton, and the University of East Anglia. The authors thank Donna Maurer for her editorial assistance. 


\section{Introduction}

Why do confident investors trade so much? Previous literature tests the ultimate relation between confidence and trading (e.g., Barber and Odean 2001; Glaser and Weber 2007; Grinblatt and Keloharju 2009), but leaves the black box of how investor confidence leads to trading unopened. Recent literature, however, points to the need to elucidate possible mechanisms by which greater or lesser confidence influences downstream financial behavior (see e.g., Parker et al. 2012: 387). It is important to have empirical evidence on the mechanism through which investor confidence affects trading, as such knowledge could help improve individual investor decision-making. Individual investors typically overtrade, which hurts their performance through the accumulation of transaction costs (Barber and Odean 2000). An increasing self-responsibility for making consequential investment choices, such as managing one's personal retirement savings (see van Rooij, Lusardi, and Alessie 2011), magnifies the relevance of the detrimental effect of trading activity on investment performance, adding to the importance of this study's research question.

Besides the lack of an empirical test of the precise role of confidence in investor belief formation and behavior, another motivation for the current study is that some of the literature's assumed mechanisms on how investor confidence relates to trading are psychologically implausible. One standard explanation for the positive relationship between investor confidence and trading relies on a model about how investors process and interpret signals about firm fundamentals (see Odean 1998). More confident investors are theorized to underestimate the variance of private signals, believe more strongly in their private signals, and overweight these signals when updating their beliefs. ${ }^{1}$ Such a model assumes that investors possess relatively advanced information-processing skills and look primarily for signals on assets' fundamental

\footnotetext{
${ }^{1}$ Related, Graham, Harvey, and Huang (2009) assume that more confident investors are more willing to act on their personal beliefs.
} 
values. Reflecting on that assumption, Cochrane (2013: 44) states that "[m]odels in which an informed trader possesses a 'signal' about the value of a liquidating dividend just don't describe the vast majority of trading. $[\ldots][\mathrm{M}]$ ost $[\ldots]$ traders $[\ldots]$ look at patterns of prices, volumes, and past trading activity, not 'information' or opinion[s] about firm fundamentals." It is unlikely that the average individual investor possesses private information about the fundamental value of assets (Coval, Hirshleifer, and Shumway 2005; Kaniel, Saar, and Titman 2008; Seasholes and Shu 2010; Døskeland and Hvide 2011). Moreover, individual investors primarily do not look at fundamental information, but instead try to interpret past price patterns (Cohen, Gompers, and Vuolteenaho 2002; Barberis, Mukherjee, and Wang 2013), consistent with naïve reinforcement learning for expected returns (see e.g., Kaustia and Knüpfer 2008; Choi et al. 2009; Greenwood and Shleifer 2014) as well as asset prices and returns in equilibrium (see Barberis et al. 2015).

We contribute to the literature on the role of confidence in individual investor belief formation and trading behavior, in two ways. First, we develop a theoretical framework which proposes a psychologically plausible mechanism through which confidence leads to trading. Second, we empirically test this mechanism in a sample of actual individual investors. In so doing, we differ from previous literature, which merely assumes rather than empirically tests the mechanism through which investor confidence translates into more trading. Responding to Cochrane's (2013) critique that current models of investor confidence and trading rely on implausible assumptions, we incorporate in our framework signals that are easy for individual investors to observe and process when updating their beliefs: individual past investment returns. We propose that investors - to varying degrees, depending on their confidence-extrapolate their past returns when forming expectations about future returns and subsequently trade based on those expectations. More confident investors rely more on intuitive judgments (Dual Process 
Theory's System 1) when forming beliefs about expected returns. In particular, they rely more on naïve reinforcement learning and extrapolate individual return experiences into the future more strongly. That is, given the same return experience, more confident investors change their beliefs more strongly, providing more reason to trade.

To test the framework, we exploit a unique dataset, consisting of two key parts. First, in collaboration with a large discount brokerage firm from the Netherlands, we commissioned a leading market research agency to develop, pretest, and program an online survey instrument to collect data on individual investors' return expectations and the confidence they have in these expectations on a monthly basis over twelve consecutive months. Second, we retrieve these investors' trading records, including information on investment returns and turnover, and match this to their survey data on return expectations and confidence. By merging these two data sources, we obtain a unique panel dataset that allows us to verify the direct link between confidence and trading as documented in the prior literature, but more importantly, to study the mechanism linking confidence and trading, which hasn't been empirically examined to date.

We find empirical support for the link between confidence and trading as proposed in the framework: Confident investors change their return expectations more strongly. The average change in return expectations for investors with above-average confidence is 0.2 units higher (on a 1 to 7 point Likert scale) than for investors with below-average confidence. Importantly, these higher changes in return expectations translate into economically significant effects on trading and performance. Investors with above-average confidence have 8.6 percentage-points higher monthly turnover than those with below-average confidence. Investors with above-average confidence underperform investors with below-average confidence by 88 basis points per month. 


\section{Theoretical Framework and Hypotheses}

Our theoretical framework connects individual investor experiences, confidence, beliefs, and trading behavior (Figure 1). Investor experiences comprise individual-level past returns. In the framework, investors first observe their returns. Based on these return experiences, investors subsequently form beliefs about future returns. That is, they update their return expectations. When updating their beliefs, investors extrapolate recent return experiences. That is, they rely on naïve reinforcement learning. Finally, investors trade on their updated beliefs. Confidence enters the framework at the stage of belief formation. Investors' confidence level interacts with their interpretation of return experiences, in that confidence stimulates the reliance on naïve reinforcement learning when updating beliefs.

[Figure 1 here]

The theoretical framework builds on previous findings on individual investor belief formation and behavior and extends the literature by including the "experience-confidence-belief" intermediate link. Dominitz and Manski (2011), Hoffmann and Post (2015), and Greenwood and Shleifer (2014) document that return expectations depend positively on experienced returns. Consistent with naïve reinforcement learning, individuals extrapolate recent experiences into future return expectations. That is, good past returns lead to optimistic expectations about future returns (and vice versa).

In response to the limitations of existing theories linking investor confidence to trading activity (see the Introduction), we incorporate in our framework signals that are easy for individual investors to observe and process (although not being informative for future returns, 
see the robustness check in Section 5.1). In particular, individual-level return experiences (past returns) provide the signal for belief formation. Investors update their beliefs (return expectations) by extrapolating recent return experiences. Investor confidence is positively related to the strength of such naïve reinforcement learning. Formally, in the spirit of Greenwood and Shleifer (2014), we hypothesize that investors form their expectations for returns according to the following equation:

$$
E_{t}\left[\text { return }_{t+1}\right]=\varphi(C O) \cdot \text { return }_{t}
$$

where $E_{t}\left[\right.$ return $\left._{t+1}\right]$ depicts investor expectations at the end of period $t$ for returns in period $t+1$ and return $_{t}$ are the returns experienced in period $t$. Greenwood and Shleifer (2014) find that the last period's returns are the most relevant for expectation formation, so for parsimony we include only one-period lagged returns. We introduce the function $\varphi(C O)$ in Equation (1). This function denotes the investor-specific strength of extrapolating past returns and is based on an investor's level of confidence $C O$ with $\varphi(C O) \geq 1$ and $\partial \varphi(C O) / \partial C O>0$. According to Equation (1), more confident investors rely more on naïve reinforcement learning when updating return expectations than their less confident counterparts (Hypothesis 1). Given the same past return experience, more confident investors will thus update their return expectations by larger magnitudes than their less confident counterparts. That is, confidence will be positively related to the magnitude of updates in investor return expectations (Hypothesis 2).

Why should investor confidence be positively related to naïve reinforcement learning? In our framework, investor confidence refers to the notion of confidence, as described in Kahneman (2011: 212, 217): "Confidence is a feeling, which reflects the coherence of the information and 
the cognitive ease of processing it. [...] [D]eclarations of high confidence mainly tell you that an individual has constructed a coherent story in his mind [...]. [...] Our understanding of cognitive ease and associative coherence locates subjective confidence firmly in System 1." More confident investors' reliance on Dual Process Theory's System 1 is associated with decisionmaking based on quick and intuitive shortcuts (System 2 is associated with slower and more effortful conscious reasoning). ${ }^{2}$ Individuals who base their judgments primarily on intuition (System 1) have high confidence in those judgments (Simmons and Nelson 2006) and use more cognitive shortcuts and heuristics than individuals who do not base their judgments primarily on intuition (Stanovich and West 2000; Evans 2008). In particular, such individuals rely more on naïve reinforcement learning (Alós-Ferrer and Hügelschäfer 2012). In the robustness check in Section 5.2, we provide evidence that investor confidence indeed relates to reliance on intuition.

We hypothesize that individual investor trading, that is, changes in demand for risky assets $D_{t}$ is linked to return expectations through:

$$
D_{t}=f\left(E_{t}\left[\operatorname{return}_{t+1}\right], Z\right)
$$

Equation (2) models demand for risky assets as a function of subjective expectations of returns and $Z$. The vector $Z$ includes various rational and behavioral reasons that may impact individual investors' decisions to trade besides their return expectations, such as expected risk, liquidity needs, sensation seeking, entertainment, and inertia. We do not aim to perfectly explain all variation in individual investor demand for risky assets, and thus do not further specify the vector $Z$. We require the investor to be a risk-averse price taker, that is, $\frac{\partial f}{\partial E_{t}\left[\text { return }_{t+1}\right]}>0$ (e.g.,

\footnotetext{
${ }^{2}$ Stanovich and West (2000), Kahneman (2003), and Evans (2008) discuss Dual Process Theory in detail.
} 
as in Diamond and Verrecchia 1981). Accordingly, changes in investor return expectations (in either direction) change investor demand for risky assets, that is, create reason to trade and thus result in more trading (Hypothesis 3). Jointly, Hypotheses 1-3 imply that, given the same return experience, more confident investors will change their beliefs more strongly than their less confident counterparts. Accordingly, they will have more reason to trade and thus trade more.

Note that by incorporating the stylized fact that individual investors extrapolate past returns, the framework can predict under certain conditions correlated behavior of investors. Thus, one may wonder how the market can clear from a general equilibrium perspective. In Section 4.3, we provide a discussion and empirical evidence regarding these issues. In general, the framework can be consistent with general equilibrium if there is heterogeneity in individual return experiences, or if other investor types (e.g., institutions) are present in the market to absorb individual investor demand and supply. For example, Barberis et al. (2015) develop a CAPM for an economy where traders extrapolate past returns, which they label "X-CAPM". The authors find that already the presence of a small share of $5 \%$ of rational traders that do not extrapolate past returns is sufficient for an equilibrium to exist (see Barberis et al. 2013: 13).

\section{Data}

In the analyses of this paper, we exploit a unique dataset, which matches brokerage records with monthly survey data for 1,376 clients of the leading discount broker in the Netherlands from April 2008 through March 2009. The sample period corresponds to a relatively volatile stockmarket period. Accordingly, there is substantial variation in individual investors' portfolio returns and return expectations, which is beneficial for testing the predictions of our framework. One may be concerned, however, about unobserved factors that could impact both the survey 
measures and the return variable, such as monthly variation in market returns during the sample period and the according swings in market sentiment. To alleviate such concerns and control for such unobserved factors, we include month fixed effects in our panel regressions (see Section 4.1 for details on our empirical setup). Individual investors in the Netherlands and the United States share similar characteristics, and finance research increasingly uses data of Dutch individuals (e.g., Dimmock and Kouwenberg 2010; van Rooij, Lusardi, and Alessie 2011; von Gaudecker, van Soest, and Wengstroem 2011; von Gaudecker 2015). Because the investors in our sample do not receive investment advice from the broker, the transactions and survey responses reflect their own decisions and opinions. The dataset has been used before, first in Hoffmann et al. (2013).

\subsection{Brokerage Records}

We have brokerage records of investors who completed at least one survey during the sample period. Apart from transaction information, the records contain information on investors' portfolio balances, demographics, and their six-digit postal code. Using data from Statistics Netherlands, we use this postal code to assign income and residential house value to investors. Dutch postal codes cover only small geographical areas (at maximum one street). Thus, the postal code level information that we retrieve from Statistics Netherlands provides a relatively close proxy for individuals' income and home value. ${ }^{3}$ Table 1 defines all variables. Table 2 provides descriptive statistics of all brokerage accounts available, and those for the subset of accounts of clients who completed the survey in each particular month of the sample period.

\footnotetext{
${ }^{3}$ Home-ownership rates in the Netherlands are high $(67.5 \%$, as of 2008 (Eurostat 2011)), as well as skewed toward wealthier households (Rouwendal 2007). Because households that invest are typically wealthier than households that do not invest (see Millward-Brown 2006), it is likely that the house values we assign to the sample of investors correspond closely to the value of the houses actually owned by the investors in the sample.
} 
[Tables 1 and 2 here]

A comparison with samples of discount brokerage clients used in other studies of individual investor behavior in the United States (Barber and Odean 2000; Barber and Odean 2001) shows that this study's sample is similar in terms of age and gender, portfolio size, and turnover. Moreover, according to a report on Dutch retail investors by Millward-Brown (2006), the account values comprise the major share of investors' total self-managed wealth. As capital gains are not taxed in the Netherlands, tax-loss-selling plays no role for the investors in the sample.

\subsection{Survey Data}

\subsubsection{Survey Design and Data Collection}

In collaboration with the discount brokerage firm, we commissioned a leading market research agency to develop, pretest, and program an online survey instrument to collect detailed data on individual investors' return expectations and the confidence investors have in these expectations. In early April 2008, the market research agency invited via email 20,000 randomly selected clients to become part of a panel that would receive a survey at the end of each month between April 2008 and March 2009. In October 2008, we sent a reminder email to these same 20,000 clients to maintain a sufficient panel size. The first survey of April 2008 was completed by 787 clients. The corresponding response rate of $3.9 \%(=787 / 20,000)$ is comparable to that of similar investor surveys (cf. Dorn and Sengmueller 2009). Over the entire sample period from April 2008 to March 2009, 1,376 clients completed the survey at least once. Of these clients, 67\% completed the survey at least 3 times, $31 \%$ completed it at least 6 times, $9 \%$ completed it at least 9 times, and 3\% completed it 12 times. Overall, 1,045 clients completed the survey for two consecutive months at least once, allowing us to identify updates in return expectations based on 
3,955 month-investor observations. A potential concern is that the monthly variation in response rate (Table 2, Panel B) could be non-random or that variation in response timing could affect the results. Robustness checks in Section 5.3 show that both concerns are not relevant in our data.

In the survey, we measure investors' return expectations and confidence therein. We also measure investors' risk perceptions and risk tolerance (as control variables). That is, we measure investors' beliefs (return expectations and risk perceptions), confidence in beliefs (regarding return expectations), and preferences (risk tolerance) for each upcoming month (Table 3). We use qualitative measures, because these are easier to understand than quantitative measures and have greater explanatory power for decision-making (Wärneryd 1996; Kapteyn and Teppa 2011).

[Table 3 here]

\subsubsection{Beliefs and Preferences}

Return expectations depict investors' optimism about the returns of their investments. Risk perceptions gauge investors' interpretations of the riskiness of their investments. Risk tolerance reflects investors' predisposition (like or dislike) toward financial risk. To ensure that we measure investors' beliefs and preferences reliably, we use multiple items (i.e., survey questions) per variable, include these items in the survey in a random order, and mix regular- and reversescored items (Netemeyer, Bearden, and Sharma 2003). After rescaling reverse-scored items, we compute the final survey measures by averaging their respective item scores. Such measures perform at least as well as those using "optimally" weighted factor scores, but have the benefit of providing a readily interpretable absolute modal meaning (Dillon and McDonald 2001).

To examine each variable's reliability, we calculate Cronbach's alpha (Cronbach 1951). Cronbach's alpha indicates the degree of interrelatedness among a set of items (i.e., survey 
questions) that measure a particular variable (e.g., return expectations). For a variable to be called reliable, Cronbach's alpha should be above 0.7 (Hair et al. 1998). Our measurements are reliable, as Cronbach's alpha ranges between 0.71 and 0.89 for the beliefs and preferences variables. The individual items within each survey measure thus pick up similar information.

The survey measures that we use are cross-validated: Levels of and changes in beliefs and preferences predict actual trading and risk-taking decisions in a consistent manner (Hoffmann et al. 2013). Finally, robustness checks in Hoffmann and Post (2015) show that most investors in the sample remember the sign of their portfolio returns correctly (between $72 \%-84 \%$, depending on the definition of what constitutes correctly remembering past returns). Thus, investors in the sample are aware of the returns they have experienced in their portfolios.

\subsubsection{Confidence}

We measure investor confidence similar to Gamble et al. (2015) by asking after each of the five questions for return expectations: "How confident are you about this answer?" (Table 3). Thus, for each investor we receive five responses for confidence per month. The final confidence measure is calculated by averaging the responses to these five confidence questions. On average, investors are relatively confident about their return expectations, as the mean (median) confidence is $5.44(5.38)$ and above the scale midpoint of 4 . We find substantial cross-sectional variation in confidence (Figure 2), while within investors, confidence is stable over time (see Section 5.2). Figure 3 shows how return expectations and confidence vary over time.

[Figures 2-3 here] 
Graphically, there appears to be a negative co-movement between return expectations and confidence. Statistically, however, there is no correlation between these two measures (Pearson correlation coefficient $=-0.010, \mathrm{p}$-value $=0.427)$. Thus, the confidence measure does not simply pick up return-expectation information nor is driven by return experiences (see robustness checks in Section 5.2). Instead, investors (to varying degrees) express confidence in both optimistic and pessimistic return expectations. Likewise, there is no correlation between confidence and risk perception $($ Pearson correlation coefficient $=-0.002, \mathrm{p}$-value $=0.831)$ and only a very marginal correlation with risk tolerance $($ Pearson correlation coefficient $=-0.032, \mathrm{p}$-value $=0.015)$.

Previous literature uses numerous measures of confidence (Moore and Healy 2008), the most important of which are overestimation (the tendency to expect higher returns than granted by the facts), overplacement (the tendency to believe that one will perform better than the average investor), and overprecision (the tendency to have too-narrow confidence intervals, also referred to as miscalibration). Tests in Section 5.2 show that, in terms of predicted investor beliefs and behavior, our confidence measure shares some, but not all features of overplacement and overprecision confidence.

Consistent with prior studies (Barber and Odean 2001; Grinblatt and Keloharju 2009), we find a direct effect of confidence on trading: More confident investors have higher turnover. Investors with above-average confidence have 8.6 percentage-points higher monthly turnover than those with below-average confidence $(\mathrm{p}$-value $=0.054)$, while investors in the highest confidence quartile have 10.3 percentage-points higher monthly turnover than other investors (pvalue $=0.049)$. 


\section{Empirical Tests}

\subsection{Confident Investors Rely More Strongly on Naïve Reinforcement Learning}

We test whether more confident investors rely more on naïve reinforcement learning. That is, we examine whether compared to less confident investors, more confident investors extrapolate return experiences more strongly when updating their return expectations (Hypothesis 1). We run panel regressions with the change in return expectations from the end of the previous month to the end of the current month (baseline specification) or levels of return expectations as the dependent variable. We include investors' portfolio returns during the current month (calculated as the product of the daily relative changes in the value of their portfolio, taking into account transaction costs and adjusting for portfolio in- and outflows) to capture return experiences and continuous interactions of these returns with investor confidence at the end of the previous month (alternatively per investor average confidence), as explanatory variables. Regarding investor time-invariant effects, we include gender, age, account tenure, income, average portfolio value, ${ }^{4}$ and house value. These variables are related to investor sophistication and experience, which drive individual investor behavior (Barber and Odean 2001; Dhar and Zhu 2006; Korniotis and Kumar 2011) and could also affect the updating of their beliefs. Bauer et al. (2009) find that investors who trade derivatives score higher on a survey question measuring whether they invest as a hobby compared to investors who do not trade derivatives. Therefore, we include an indicator of derivatives trading (Derivatives) as a time-variant control capturing potential alternative trading motivations, such as entertainment. We include month fixed effects to control

\footnotetext{
${ }^{4}$ We include the average of the portfolio value instead of the time-variant monthly portfolio value, because the monthly value is highly correlated with investors' returns. Instead of using the per-postal-code assigned income and residential house value control variables, we alternatively estimate model specifications with three-digit postal-code fixed effects and two-way clustered standard errors (investor and postal code). Results (available on request) are consistent with the current specification. Thus, unobserved location-specific factors other than income and house value (such as overall wealth, education, or information) do not explain our results.
} 
for unobserved factors that could impact both the survey measures and the return variable (such as monthly variation in market returns). By including these controls, we measure the distinct effects of individual return experiences and confidence on investor return expectations (see Table 4).

[Table 4 here]

In the first and second columns of Table 4, we document return-experience-based naïve reinforcement learning. In particular, the positive coefficient on experienced returns indicates that investors extrapolate individual return experiences when updating their return expectations. ${ }^{5}$ In the third column, which is the baseline specification, we extend model (1) by including confidence at the end of the previous month, and an interaction of that variable with returns, as independent variables. The third column provides supporting evidence for Hypothesis 1: The interaction term of confidence and returns is positive and significant. This result indicates that more confident investors extrapolate recent return experiences more strongly when forming expectations about future returns. ${ }^{6}$

The fourth column shows that the results do not differ substantially if we relate changes in beliefs alternatively to per investor sample-period average confidence. ${ }^{7}$ This result is consistent with a robustness check reported in Section 5.2 which shows that confidence, being related to a certain type of decision maker, is stable within investors. Finally, the fifth column documents

\footnotetext{
${ }^{5}$ Because of the qualitative nature of the return-expectations data, this regression model is not directly estimating $\varphi$ from Equation (1). As we do not include the trading indicators D_Trade and Turnover as control variables (because of the relation to confidence), the coefficient on past returns is different than that in Hoffmann and Post (2015).

${ }^{6}$ The coefficient for past return is insignificant in this specification, but the three coefficients for past return, confidence, and the interaction term of both these variables are jointly significant at the $1 \%$ level (p-value $=0.000)$. The coefficient for past return is negative in this specification. Thus, investors with very low levels of confidence (below 2.89) would actually depict a reversed extrapolation bias. Only $0.73 \%$ of observations are below this threshold, and thus such a reversed extrapolation bias has little empirical relevance.

${ }^{7}$ This also holds for the analyses testing Hypotheses 2 and 3.
} 
that when, alternatively, we regress levels of beliefs on investor confidence in an individual fixed-effects model, the confidence and confidence return interaction terms are no longer significant. That is, the very small (if any) time variation in investor confidence in the sample (see Section 5.2) does not drive our results.

\subsection{Confident Investors Change Their Return Expectations More Strongly}

Next, we analyze the link between investor confidence and magnitudes of changes in beliefs. That is, we test Hypothesis 2, according to which more confident investors change their beliefs more strongly. In this section we focus on the absolute value of changes in return expectations, as both positive and negative updates in return expectations provide reason for trading (see Section 4.3). Figure 4 plots the average of the absolute values of the changes in return expectations against previous month's confidence deciles. This figure suggests that investor confidence is positively related to the absolute magnitude of updates in beliefs.

[Figure 4 here]

We test the significance of the relation of confidence and the absolute magnitudes of updates of return expectation $\left(=\mathrm{ABS}\left[\right.\right.$ Return $_{\text {Expectation }_{\mathrm{t}}}-$ Return $\left.\left._{\text {Expectation }} \mathrm{t}-1\right]\right)$ using panel regressions with the same set of explanatory variables as those used in Section 4.1. We now estimate the direct impact of investor confidence on the absolute magnitude of changes in beliefs. That is, we model the effect of investor confidence on changes in beliefs, irrespective of the direction of these changes in beliefs.

[Table 5 here] 
The first column of Table 5 shows that investor confidence is positively and significantly related to the magnitudes by which investors update their return expectations. We find support for Hypothesis 2: More confident investors change their beliefs more strongly. When controlling for the standard deviation of returns in investors' portfolios (see second column in Table 5), the effect of confidence on the magnitudes of updates in return expectations remains significant. Thus, higher magnitudes of updates by confident investors are not driven merely by more volatile return experiences (see the related robustness check in Section 5.3). Finally, in the third column, we use the log of absolute magnitudes of updates of return expectations as an alternative dependent variable, to account for skewness in the dependent variable that is introduced through the absolute-value transformation, yielding results that are consistent with those reported before. Past returns are no longer significant in all three specifications, as they impact directional changes in return expectations that average out through the absolute-value transformation.

\subsection{Investors Who Change Their Return Expectations More Strongly Trade More}

Finally, we test whether investors who change their beliefs more strongly also trade more (Hypothesis 3). First, we test the foundation for Hypothesis (3), that is, Equation (2), which proposes a positive relation between expected returns and demand for risky assets. Then, we test Hypothesis (3) by regressing trading activity (Turnover) on updates in return expectations.

To test Equation (2), we regress the fraction of an investor's total account value (portfolio value + cash) invested in risky assets at the end of a particular month $t$ on investor return expectations at the beginning of the month (Return Expectation t -1 ) in a model with month and individual fixed effects. That is, we test whether the time variation in expected returns explains subsequent changes in demand for risky assets proxied by movements within an account from 
cash to the investment portfolio. ${ }^{8}$ As time-varying control variables, we include the portfolio return of the current month (controlling for the passive effect of portfolio returns on the composition of the account value), investor risk perception and risk tolerance at the beginning of the month, and an indicator of derivatives trading. Results in Table 6 are in line with the prediction of Equation (2): Higher return expectations increase investor demand for risky assets.

\section{[Table 6 here]}

Next, we regress the turnover of investors that traded in a particular month $\left(=\right.$ Turnover $\left._{t}\right)$ on the lagged absolute changes in return expectations $\left(=\mathrm{ABS}\left[\right.\right.$ Return Expectation $_{\mathrm{t}-1}-$ Return Expectation $\left._{\mathrm{t}-2}\right]$ ) and a set of control variables. That is, we examine the link between investors' trading activity in a particular month and the magnitude of the absolute value of the update in their return expectations over the preceding month.

\section{[Table 7 here]}

The results in the first column of Table 7 support Hypothesis 3: Investors who change their beliefs (return expectations) more strongly have higher turnover in the subsequent period. That is, larger changes in beliefs provide more reason to trade. This result also holds when we control for investors' risk tolerance and risk perception (second column), ruling out the possibility that the effect of confidence on trading would not work through more confident investors' stronger

\footnotetext{
${ }^{8}$ Because of limitations of the portfolio data, we do not have a breakdown of assets within a portfolio available. We cannot rule out that some portfolio positions are, similar to cash, invested risk-free. However, the asset classification available for investors' transactions indicates that potentially risk-free investments (bonds) make up only 1.6\% of total trading volume. That is, investor' portfolios most likely include primarily risky assets.
} 
updates in beliefs, but instead would work through their risk tolerance and risk perception, which might relate to confidence and intuitive judgments (Dorn and Huberman 2005; Butler, Guiso, and Jappelli 2013). Using either log turnover (accounting for the skewness of this variable) or the $\log$ number of transactions as an alternative dependent variable provides consistent evidence (third and fourth columns).

Finally, Table 8 presents information on the heterogeneity in investors' return experiences, changes in return expectations, and absolute changes in return expectations. Table 8 shows that within the cross-section of investors in each month, there is substantial variation in the magnitude of returns, the sign of returns achieved (positive vs. negative), the magnitude and direction of changes in return expectations, and the magnitude of absolute changes in return expectations. That is, next to changes in beliefs as one precondition of trading, we observe a second precondition for trading: There is heterogeneity in the magnitude and direction of changes in beliefs. That is, there are differences in beliefs and changes in those differences. Accordingly, investors with reason to trade will be able to find a trading counterpart. Moreover, even if the changes in beliefs (and thus behavior) of different individual investors might be correlated (as they form expectations based on potentially correlated past returns), institutional traders can absorb individual investor demand and supply (Cohen, Gompers, and Vuolteenaho 2002). Likewise, firms tend to issue equity when stock markets perform well (Baker and Wurgler 2000; Baker and Wurgler 2009), thereby absorbing correlated demand from individual investors.

[Table 8 here] 


\section{Robustness Checks}

\subsection{Rationality of Reliance on Naïve Reinforcement Learning}

Our theoretical framework links investors' return expectation formation to confidence, in that more confident investors rely more on naïve reinforcement learning and thus extrapolate recent return experiences more strongly than less confident investors. Based on the same data, Hoffmann and Post (2015) show that, on average, extrapolating recent return experiences when forming return expectations is not rational, because it is not associated with achieving higher returns. In line with previous studies (e.g., Welch and Goyal 2008), the return-generating process in our sample does not exhibit predictability or momentum, and return expectations do not contain information on investors' skills or subsequent performance. Investor confidence, however, might contain information related to superior trading skills, so that it would be rational for more confident investors to extrapolate recent return experiences more strongly compared to less confident investors. To examine this possibility, we regress investor returns on past return expectations, past confidence, and an interaction term for past return expectations with investor confidence.

Table 9 shows that neither past return expectations alone (first column), nor investor confidence and its interaction with return expectations (second column) are significantly related to investor returns. That is, investor confidence is not correlated with superior skills. If we exclude from the model variables that are related to investor confidence, that is, return expectations (related to confidence when forming beliefs) and trading indicators (related to confidence as confidence triggers trades through changing beliefs), investor confidence has a significantly negative effect on investor returns (third column). That is, through the belief formation-trading channel, high levels of confidence have a negative impact on investor returns. 
The negative impact of investor confidence on returns is economically relevant. The difference in means of the monthly returns between investors with above-average confidence and belowaverage confidence (without controlling for any investor characteristics) is 88 basis points (pvalue $=0.012) .{ }^{9}$ To conclude, it is not rational for more confident investors to extrapolate recent return experiences to the future more strongly. If anything, these investors' more strongly changing beliefs hurt their performance through higher turnover. Evaluating alternative performance measures (i.e., Sharpe Ratio, Jensen's Alpha) yields consistent evidence (detailed results available on request).

[Table 9 here]

\subsection{Investor Confidence: Reliance on Intuition and Use of Intuitive Shortcuts and Heuristics}

In our theoretical framework, we link investor confidence with reliance on intuition and the use of intuitive shortcuts and heuristics. Our results (stronger reliance on naïve reinforcement learning by more confident investors) are consistent with such a link between confidence and reliance on intuition and heuristics, but we cannot directly test this link with the available data. Thus, in the following we perform additional robustness checks. First, to test whether investor confidence is indeed a rather general personality characteristic, we analyze whether it is relatively stable over time within a person as predicted by several studies in psychology (Stanovich and West 2000; Evans 2003; Evans 2008; Alós-Ferrer and Hügelschäfer 2012). Second, to check whether investor confidence is related to reliance on intuition and heuristics,

\footnotetext{
${ }^{9}$ Controlling for investor characteristics leads to similar estimates. Based on Table 9 column (3), the coefficient for confidence is -0.007 . Average confidence for the subset of investors above the overall average of 5.442 is 6.167 , for investors below the overall average it is 4.751 . Multiplying the confidence difference between these subgroups of $1.416(=6.167-4.751)$ with -0.007 gives an estimated monthly return differential of -0.0099 , that is, 99 basis points.
} 
we test whether it has a systematic relationship with other beliefs of investors that are driven by return experiences, even when investor confidence is measured in the context of return expectations. Third, we present additional evidence from a subsample of investors that in a 2006 survey was asked to indicate if they base their investment decisions primarily on intuition.

To test whether our measure of investor confidence relates to a certain type of individual (i.e., one who relies more or less on intuition in general), we first examine how the crosssectional mean of confidence changes over time. Confidence varies from month to month, but not by large amounts, and in most cases not significantly. The average of the 11 monthly absolute changes of confidence (measured on a scale from 1 to 7 ) is 0.1 . Of the 11 changes, one is statistically significant at the 1\% level (August-September 2008), two are significant at the 5\% level (October-November 2008, January-February 2009), and one is significant at the $10 \%$ level (May-June 2008) (see Figure 3). Second, we examine within-investor changes in confidence. We find a high correlation coefficient of 0.65 (p-value $=0.000)$ between an investor's current month's confidence and his or her previous month's confidence. Likewise, the correlations are high over longer time intervals. For example, the correlation coefficient over a six month interval is 0.53 (p-value $=0.000)$ and over twelve months it is $0.58(\mathrm{p}$-value $=0.000)$. Also, the average cross-sectional standard deviation of confidence (0.99) is larger than the average withininvestor's time-series standard deviation (0.55). Sorting investors into deciles based on their confidence in the previous month and then calculating the average value of current month's confidence for each decile provides supporting evidence (see Figure 5). That is, Figure 5 indicates that if an investor was in a high (low) confidence decile in the previous month, he or she is also more likely to have high (low) confidence in the current month. In addition, a transition matrix (see Table 10) shows that transition probabilities are highest along the diagonal. 
Hence, we find evidence that our measure of investor confidence refers to a certain type of individual, as it is stable over time.

Moreover, there is no evidence that any of the small fluctuations in investor confidence are driven by past returns, that is, that high returns lead investors to learn to be overconfident (Gervais and Odean 2001). In Table 11, we regress investor confidence on past returns. The first (no fixed-effects) and second (time fixed-effects) columns show a negative and significant relation between investor confidence and returns, while no significant effect is present in the third (changes in confidence as dependent variable) and fourth columns (levels as dependent variable including both time and individual fixed-effects). That is, confident investors generally have lower returns (because of their higher turnover, see Section 5.1), but variation in those lower returns does not change their confidence. ${ }^{10}$ This result also holds when we include an indicator variable for investors having positive returns, to test for potential asymmetry in the effect of past returns on investor confidence. That is, it is not the case that investors increase their confidence after positive returns, but not after negative returns or vice versa (column 5).

[Figure 5 here]

[Tables 10-11 here]

Hoffmann and Post (2015) find that among beliefs, not only return expectations, but also investors' risk perceptions are driven by reliance on naïve reinforcement learning regarding past returns. If confidence is indeed a rather general personality characteristic and related to reliance on intuition, then investors who are more confident about their return expectations, and display

\footnotetext{
${ }^{10}$ The regression also shows that females are more confident than males. This effect is in line with the role of confidence in our framework, that is, reliance on intuition. It is also consistent with the evidence on reliance on intuition and gender differences in Butler et al. (2013).
} 
greater updates in those expectations, should also display greater updates in their risk perceptions. To check for this possibility, we regress the absolute changes in risk perception on past confidence with the same set of control variables as used in the return-expectation regression in Section 4.2. We find that confidence has a significant and positive impact on the magnitude of changes for risk perceptions. The coefficient for confidence in the risk perception regression is $0.092(\mathrm{p}$-value $=0.000)($ compare to the return expectation results in Table 5, model (1)). Thus, although confidence is measured with respect to an individual's return expectation, it seems to reflect a more general personality trait, as it interacts in a consistent way with how an individual updates his or her risk perception. Note that investor confidence itself is not correlated to the risk perception measure $($ Pearson correlation coefficient $=-0.002$, $\mathrm{p}$-value $=0.831)$. That is, investor confidence is not proxying for the perceived riskiness of investment returns.

We find further supporting evidence for a link between investor confidence and reliance on intuition using additional information from a 2006 survey with the same broker where investors were asked to indicate based on which method or information source (i.e., technical analysis, fundamental analysis, financial news, professional advice, family acquaintances, own intuition) they trade (see Hoffmann and Shefrin (2014) for details on this survey). Matching respondents of the 2006 survey with the current survey yields a sample of 245 investors for whom we have both information on confidence and the method or information source used for forming decisions. Using this subset of the sample, we compare the fraction of investors that indicate to rely exclusively on intuition for making their decisions between investors with high and low (average) confidence. Indeed, more confident investors indicate to more often rely only on their intuition. The difference in the fraction of investors relying only on intuition between investors 
in the top confidence quartile and bottom confidence quartile is $6.11 \%$. This difference, however, is not statistically significant $(\mathrm{p}$-value $=0.205)$, potentially because of the small sample size.

\subsection{Survey Data Quality}

A general concern with survey data is that the variation in response rate could be non-random. To examine this possibility, we estimate a panel probit model where survey participation is explained by the main variables of interest, that is, investor confidence, return expectations, returns, and turnover. For confidence and return expectations, we use the sample period average per investor, because for non-participating investors, the information is not available. This regression only yields a significant coefficient $(0.030)$ for turnover ( $\mathrm{p}$-value $=0.001$ ), indicating that investors with higher turnover are more likely to participate in the survey. The economic significance of this effect, however, is small: A one-standard deviation increase of turnover from the mean increases the probability to participate in the survey by $1.45 \%$. Nevertheless, we additionally account for potential non-random response effects in the regression model explaining turnover (Table 7) by applying an inverse-probability-weighted estimator (Robins and Rotnitzky 1995; Wooldridge 2002). For each of the 12 months, we estimate a logit model where the dependent variable indicates either response (1) or non-response (0) to the survey. As explanatory variables, we include confidence, return expectations, returns, and turnover. Next, the predicted probabilities of survey response are calculated. Finally, the turnover regression models are estimated again using the inverse of the predicted probabilities as sample weights. The results obtained are similar to the original specifications in terms of coefficient magnitudes, significance, and signs (detailed results available upon request). For example, the coefficient for 
the lagged absolute change in return expectations becomes 0.080 (p-value $=0.005)$ (compare Table 7, model 1). Overall, our results are thus not impacted by non-random response behavior.

Another potential concern is response timing potentially affecting the results. In particular, beliefs and confidence of early versus late respondents in each month might differ because of changes in individual portfolio returns between their response days. As the majority of survey response $(85 \%)$ is received within the first five days after we sent out each survey email, it is unlikely that there is a response-time pattern that could lead to a possible bias. When estimating all models excluding late respondents (more than five days response time), we obtain similar results compared to the original specifications in terms of coefficient magnitudes, significance, and signs (detailed results available upon request). That is, response timing is not a concern.

To measure investors' return expectations, we use survey items that have been used and cross-validated in a previous study (Hoffmann et al. 2013). In the context of the present study, however, the third survey item of the return expectation measure ("Next month, my investments will have a worse performance than those of most other investors") could raise some concerns. That is, because of the wording of this question, it could potentially pick up investor confidence in its overplacement variant (the better-than-average effect). If this is the case, our finding that updates in return expectations are related to investor confidence might be driven by regressing one confidence measure on another. To check for this possibility, we rerun the main analyses, but now exclude this survey item when calculating the measure for return expectations, as well the corresponding question for confidence when calculating the measure for investor confidence. The results of this robustness check are consistent with the main results, as reported previously: Based on these revised return expectations and confidence measures, the correlation coefficient of confidence with return expectations remains close to zero (Pearson correlation coefficient $=-$ 
0.054 , p-value $=0.000$ ), and the correlation of the current month's confidence with the previous month's confidence remains high (Pearson correlation coefficient $=0.619$, p-value $=0.000$ ). Moreover, the coefficient of the confidence interaction term with past returns in the changes in the return-expectation regression is positive $(0.196)$ and significant ( $\mathrm{p}$-value $=0.015$ ) (compare with the original results in the third column of Table 4), the coefficient on confidence in the absolute changes in the return-expectation regression is positive $(0.102)$ and significant ( $\mathrm{p}$-value $=0.000)$ (compare with Table 5), and the coefficient on the lagged absolute changes in return expectations in the turnover regression is positive (0.086) and significant (p-value $=0.003$ ) (compare with Table 7).

In general, the confidence measures used in previous work are elicited by numerical survey questions (prediction tasks). Because we do not have corresponding questions in our survey, it is difficult to identify if and to which of the previously used confidence measures our measure is most closely related. Based on the predictions of the effect of investor confidence on beliefs and behavior that differ among the three types of confidence, however, we can check with which confidence measure our measure overlaps the most. In particular, overestimation confidence predicts that return expectations are higher for more confident investors without being justified by higher returns. Overplacement confidence predicts that investors with high confidence expect to achieve higher returns relative to other investors. Overprecision (i.e., miscalibration) confidence predicts that investors with more confidence hold riskier portfolios than those that would be granted by their beliefs (return expectations, risk perception) and preferences (risk tolerance). We can test these predictions with the data available. First, we can rule out overestimation confidence because of the absence of a correlation between return expectation and confidence, as reported in Section 3.2.3, and the fact that more confident investors do not 
achieve higher returns (see robustness checks in Section 5.1). Second, with respect to overplacement, we can exploit survey item number three for return expectations (Table 3), which reads, "Next month, my investments will have a worse performance than those of most other investors." If our confidence measure is related to overplacement, then the correlation of confidence with this return-expectation item should be positive (as it is a reverse-scored item). The correlation of the third return-expectation item with our confidence measure is 0.080 (pvalue 0.000). ${ }^{11}$ Although the correlation is not large, this result is generally consistent with overplacement confidence. To check for overprecision confidence, we regress investor portfolio risk (standard deviation) on lagged confidence, while controlling for lagged beliefs (return expectations, risk perception) and preferences (risk tolerance), and the set of controls discussed in Section 4.1. Results in Table 12 show that our confidence measure is significantly related to higher portfolio risk, even after controlling for investor beliefs and preferences. This evidence is consistent with predictions from overprecision confidence.

[Table 12 here]

Thus, based on these results, we cannot discriminate between overplacement and overprecision confidence. But, we can again use the additional information from the 2006 survey with the same broker. In that survey investors were asked to rate their competence as investors by selfcategorizing as a "novice investor," an "advanced investor," or a "very advanced investor" (see Hoffmann and Shefrin (2014) for details on this survey). Based on the results of Graham et al.

\footnotetext{
${ }^{11}$ Alternatively, we calculate the correlation between (1) our confidence measure when we exclude its third item and the return expectation measure excluding its third item, and (2) only the third item of our confidence measure with the third item of our return expectation measure. In both cases, we find correlations of similar magnitude ( 0.083 vs. $0.073)$, that are both significant $(\mathrm{p}$-value $=0.000)$.
} 
(2009), investors' perceived competence should be positively related to overplacement confidence. Thus, if our confidence measure relates to overplacement rather than overprecision, we expect a positive relationship between confidence and self-rated competence. In the matched subset of the sample (245 investors), average confidence for the investors does not increase with competence. The average of confidence is 5.50 for the "novice" group, 5.31 for the "advanced" group, and 5.44 for the "very advanced" group. Differences among the groups, however, are not statistically significant. Based on these tests' results, our confidence measure overlaps the most with overprecision confidence. Direct tests of confidence-trading links in Glaser and Weber (2007), however, do find a positive relation of overplacement with trading, but no relation of overprecision with trading. We thus conclude that our confidence measure is unrelated to overestimation, while it shares some but not all features of overplacement and overprecision.

A final potential concern with respect to the quality of the survey measures is that they are measured on a Likert scale that ranges from 1 to 7 . Thus, investors that have responses at or close to the scales' upper or lower limit in a certain month might not be able to express updates in their return expectations for the next month or confidence therein appropriately. To test the robustness of the results, we exclude all observations for a particular month where return expectations or confidence values are smaller than 2 or larger than 6 in the respective previous month and estimate the models of Section 4 again on the resulting subsample. The results confirm the findings: Within investors, confidence is stable over time (see Section 5.2), more confident investors rely more on naïve reinforcement learning and exhibit larger absolute updates of their return expectations (see Section 4) (detailed results available upon request). 


\section{Conclusion and Discussion}

More confident investors trade more than less confident investors, but why? Prior research tests the ultimate relation between investor confidence and trading, but does not empirically examine the intermediate stage, that is, the underlying mechanism that explains why confidence leads to trading. We complement the literature by developing a theoretical framework and presenting empirical evidence on a psychologically plausible mechanism through which confidence leads to trading. In particular, we connect investor confidence and trading by introducing an "experienceconfidence-belief" intermediate link. In the theoretical framework, investors first observe their returns. Based on these return experiences, they form beliefs about future returns (return expectations). When updating their beliefs, investors extrapolate recent return experiences. Confident investors, who use more Dual Process Theory's System 1, rely more on such naïve reinforcement learning. That is, given the same return experience, confident investors change their beliefs more strongly, have more reason to trade than less confident investors, and thus trade more. Ultimately, confident investors' higher turnover hurts their return performance. In particular, investors with above-average confidence have 8.6 percentage-points higher monthly turnover than investors with below-average confidence. Finally, investors with above-average confidence underperform investors with below-average confidence by 88 basis points per month.

To the extent that high trading volume reduces investors' performance, our results have potential implications for developing smart defaults, frames, or nudges that might attenuate individual investors' tendency for portfolio churning. Previous literature finds that, for example, manipulating portfolio-evaluation periods or information-aggregating levels can affect investors' beliefs and behavior (see e.g., Gneezy and Potters 1997; Gneezy, Kapteyn, and Potters 2003; Beshears et al. 2011). Accordingly, especially confident investors might benefit from defaults 
that display their return experiences in a way such that they appear less volatile, which would potentially lead to smaller updates in their beliefs, thus giving them less reason to trade. 


\section{References}

Alós-Ferrer, C. and S. Hügelschäfer (2012), "Faith in Intuition and Behavioral Biases," Journal of Economic Behavior and Organization, 84(1), 182-92.

Baker, M. and J. Wurgler (2000), "The Equity Share in New Issues and Aggregate Stock Returns.," Journal of Finance, 55(5), 2219-57.

Baker, M. and J. Wurgler (2009), "Under New Management: Equity Issuance and the Attribution of Past Returns," working paper (Harvard University).

Barber, B. M. and T. Odean (2000), "Trading is Hazardous to Your Wealth: the Common Stock Investment Performance of Individual Investors," Journal of Finance, 55(2), 773-806.

Barber, B. M. and T. Odean (2001), "Boys Will be Boys: Gender, Overconfidence, and Common Stock Investment," Quarterly Journal of Economics, 116(1), 261-92.

Barberis, N., R. Greenwood, L. Jin, and A. Shleifer (2013), "X-CAPM: An Extrapolative Capital Asset Pricing Model," NBER Working Paper No.19189.

Barberis, N., R. Greenwood, L. Jin, and A. Shleifer (2015), "X-CAPM: An Extrapolative Capital Asset Pricing ," Journal of Financial Economics, 115(1), 1-24.

Barberis, N., A. Mukherjee, and B. Wang (2013), "First Impressions: "System 1" Thinking and the Cross-section of Stock Returns," working paper (Yale).

Bauer, R., M. Cosemans, and P. M. A. Eichholtz (2009), "Option Trading and Individual Investor Performance," Journal of Banking and Finance, 33(4), 731-46.

Beshears, J., J. Choi, D. Laibson, and B. Madrian (2011), "Does Aggregated Returns Disclosure Increase Portfolio Risk-Taking?," working paper (Stanford University).

Butler, J. V., L. Guiso, and T. Jappelli (2013), "Manipulating Reliance on Intuition Reduces Risk and Ambiguity Aversion," CEPR Discussion Paper No.9461. 
Choi, J., D. Laibson, B. Madrian, and A. Metrick (2009), "Reinforcement Learning and Savings Behavior," Journal of Finance, 64(6), 2515-34.

Cochrane, J. H. (2013), "Finance: Function matters, not Size," Journal of Economic Perspectives, 27(2), 29-50.

Cohen, R. B., P. A. Gompers, and T. Vuolteenaho (2002), "Who Underreacts to Cash-Flow News? Evidence from Trading Between Individuals and Institutions," Journal of Financial Economics, 66(2-3), 409-62.

Coval, J. D., D. Hirshleifer, and T. Shumway (2005), "Can Individual Investors Beat the Market?," working paper (Harvard University).

Cronbach, L. J. (1951), "Coefficient Alpha and the Internal Structure of Tests," Psychometrika, 16(3), 297-334.

Dhar, R. and N. Zhu (2006), "Up Close and Personal: Investor Sophistication and the Disposition Effect," Management Science, 52(5), 726-40.

Diamond, D. W. and R. E. Verrecchia (1981), "Information Aggregation in a Noisy Rational Expectations Economy," Journal of Financial Economics, 9(3), 221-35.

Dillon, W. R. and R. McDonald (2001), "How to Combine Multiple Items into a Composite Score," Journal of Consumer Psychology, 10(1/2), 62-4.

Dimmock, S. G. and R. Kouwenberg (2010), "Loss-Aversion and Household Portfolio Choice," Journal of Empirical Finance, 17(3), 441-59.

Dominitz, J. and C. F. Manski (2011), "Measuring and Interpreting Expectations of Equity Returns," Journal of Applied Econometrics, 26(3), 352-70.

Dorn, D. and G. Huberman (2005), "Talk and Action: What Individual Investors Say and What They Do," Review of Finance, 9(4), 437-81. 
Dorn, D. and P. Sengmueller (2009), "Trading as Entertainment?," Management Science, 55(4), 591-603.

Døskeland, T. M. and H. K. Hvide (2011), "Do Individual Investors Have Asymmetric Information Based on Work Experience?," Journal of Finance, 66(3), 1011-41.

Eurostat (2011), "Distribution of Population by Tenure Status, Type of Household and Income Group," retrieved from http://appsso.eurostat.ec.europa.eu/nui/show.do?dataset=ilc_lvho02\&lang=en.

Evans, J. S. B. T. (2003), "In Two Minds: Dual-Process Accounts of Reasoning," Trends in Cognitive Sciences, 7(10), 454-9.

Evans, J. S. B. T. (2008), "Dual-Processing Accounts of Reasoning, Judgment, and Social Cognition," Annual Review of Psychology, 59(1), 255-78.

Gamble, K. J., P. A. Boyle, L. Yu, and D. A. Bennett (2015), "Aging and Financial Decision Making," Management Science, 61(11), 2603-10.

Gervais, S. and T. Odean (2001), "Learning to be Overconfident," Review of Financial Studies, $14(1), 1-27$.

Glaser, M. and M. Weber (2007), "Overconfidence and Trading Volume," Geneva Risk and Insurance Review, 32(1), 1-36.

Gneezy, U., A. Kapteyn, and J. Potters (2003), "Evaluation Periods and Asset Prices in a Market Experiment," Journal of Finance, 58(2), 821-38.

Gneezy, U. and J. Potters (1997), "An Experiment on Risk Taking and Evaluation Periods," Quarterly Journal of Economics, 112(2), 631-45.

Graham, J. R., C. R. Harvey, and H. Huang (2009), "Investor Competence, Trading Frequency, and Home Bias," Management Science, 55(7), 1094-106. 
Greenwood, R. and A. Shleifer (2014), "Expectations of Returns and Expected Returns," Review of Financial Studies, 27(3), 714-46.

Grinblatt, M. and M. Keloharju (2009), "Sensation Seeking, Overconfidence, and Trading Activity," Journal of Finance, 64(2), 549-78.

Hair, J. F., R. E. Anderson, R. L. Tatham, and W. C. Black (1998), Multivariate Data Analysis. Upper Saddle River, New Jersey: Prentice Hall.

Hoffmann, A. O. I. and T. Post (2015), "How Return and Risk Experiences Shape Investor Beliefs and Preferences," Accounting and Finance, Forthcoming.

Hoffmann, A. O. I., T. Post, and J. M. E. Pennings (2013), "Individual Investor Perceptions and Behavior During the Financial Crisis," Journal of Banking and Finance, 37(1), 60-74.

Hoffmann, A. O. I. and H. Shefrin (2014), "Technical Analysis and Individual Investors," Journal of Economic Behavior and Organization, 107(November), 487-511.

Kahneman, D. (2003), "Maps of Bounded Rationality: Psychology for Behavioral Economics," American Economic Review, 93(5), 449-89.

Kahneman, D. (2011), Thinking, Fast and Slow. New York: Farrar, Straus and Giroux.

Kaniel, R., G. Saar, and S. Titman (2008), "Individual Investor Trading and Stock Returns," Journal of Finance, 63(1), 273-310.

Kapteyn, A. and F. Teppa (2011), "Subjective Measures of Risk Aversion, Fixed Costs, and Portfolio Choice," Journal of Economic Psychology, 32(4), 564-80.

Kaustia, M. and S. Knüpfer (2008), "Do Investors Overweight Personal Experience? Evidence from IPO Subscriptions," Journal of Finance, 63(6), 2679-702.

Korniotis, G. M. and A. Kumar (2011), "Do Older Investors Make Better Investment Decisions?," Review of Economics and Statistics, 93(1), 244-65. 
Millward-Brown (2006), The Retail Investor 2006: Developments in the Market of Retail Investors in the Netherlands. Amsterdam, The Netherlands.

Moore, D. O. and P. J. Healy (2008), "The Trouble With Overconfidence," Psychological Review, 115(2), 502-17.

Netemeyer, R. G., W. O. Bearden, and S. Sharma (2003), Scaling Procedures: Issues and Applications. Thousand Oaks, California: Sage Publications.

Odean, T. (1998), "Volume, Volatility, Price, and Profit When All Traders Are above Average," Journal of Finance, 53(6), 1887-934.

Parker, A. M., W. Bruine de Bruin, J. Yoong, and R. Willis (2012), "Inappropriate Confidence and Retirement Planning: Four Studies with a National Sample," Journal of Behavioral Decision Making, 25(4), 382-9.

Robins, J. M. and A. Rotnitzky (1995), "Semiparametric Efficiency in Multivariate Regression Models," Journal of the American Statistical Association, 90(429), 122-9.

Rouwendal, J. (2007), "Mortgage interest deductibility and homeownership in the Netherlands," Journal of Housing and the Build Environment, 22(4), 369-82.

Seasholes, M. and N. Shu (2010), "Individual Investors and Local Bias," Journal of Finance, 65(5), 1987-2010.

Simmons, J. P. and L. D. Nelson (2006), "Intuitive Confidence: Choosing Between Intuitive and Nonintuitive Alternatives," Journal of Experimental Psychology: General, 135(3), 40928.

Stanovich, K. E. and R. F. West (2000), "Individual Differences in Reasoning: Implications for the Rationality Debate? " Behavioral and Brain Sciences, 23(5), 645-65. 
van Rooij, M., A. Lusardi, and R. Alessie (2011), "Financial Literacy and Stock Market Participation," Journal of Financial Economics, 101(2), 449-72.

von Gaudecker, H.-M. (2015), "How Does Household Portfolio Diversification Vary with Financial Sophistication and Advice?," Journal of Finance, 70(2), 489-507.

von Gaudecker, H.-M., A. van Soest, and E. Wengstroem (2011), "Heterogeneity in Risky Choice Behavior in a Broad Population," American Economic Review, 101(2), 664-94.

Wärneryd, K.-E. (1996), "Risk Attitudes and Risky Behavior," Journal of Economic Psychology, 17(6), 749-70.

Welch, I. and A. Goyal (2008), "A Comprehensive Look at The Empirical Performance of Equity Premium Prediction," Review of Financial Studies, 21(4), 1455-508.

Wooldridge, J. M. (2002), "Inverse Probability Weighted M-Estimation for Sample Selection, Attrition, and Stratification," Portuguese Economic Journal, 1(2), 117-39. 
Table 1

\section{Variable Definitions}

\begin{tabular}{|c|c|}
\hline Variable & Definition \\
\hline Gender & Indicator variable taking the value 0 for male investors and 1 for female investors. \\
\hline Age & Age of the investor in years as of April 2008. \\
\hline Account Tenure & Account tenure of the investor in years as of April 2008. \\
\hline Income & $\begin{array}{l}\text { Annual disposable income in } 2007 \text { (equals gross income minus taxes, social-security } \\
\text { contributions, and health insurance premiums paid). Assigned to each investor based } \\
\text { on his or her 6-digit postal code. This postal code is unique for each street in the } \\
\text { Netherlands. Data source is the average net income per 6-digit postal code from } \\
\text { Statistics Netherlands (Central Bureau of Statistics). }\end{array}$ \\
\hline Portfolio Value & Value of the investment assets in an investor's account at the end of the month. \\
\hline $\begin{array}{l}\text { Fraction of Account } \\
\text { Invested }\end{array}$ & $\begin{array}{l}\text { Portfolio value at the end of the month divided by total account value (= portfolio } \\
\text { value }+ \text { cash) }\end{array}$ \\
\hline House Value & $\begin{array}{l}\text { Value of the house in 2008. Assigned to each investor based on his or her 6-digit } \\
\text { postal code. This postal code is unique for each street in the Netherlands. Data source } \\
\text { is the average residential house value per 6-digit postal code from Statistics } \\
\text { Netherlands (Central Bureau of Statistics). }\end{array}$ \\
\hline Derivatives & $\begin{array}{l}\text { Indicator variable taking the value } 1 \text { if an investor traded an option or futures contract } \\
\text { at least once during a particular month; } 0 \text { otherwise. }\end{array}$ \\
\hline Traded & $\begin{array}{l}\text { Indicator variable taking the value } 1 \text { if an investor traded in a particular month; } 0 \\
\text { otherwise. }\end{array}$ \\
\hline Turnover & $\begin{array}{l}\text { Average of the absolute values of all purchases and sales in a particular month, } \\
\text { divided by the average of the portfolio values at the beginning and end of a particular } \\
\text { month. }\end{array}$ \\
\hline Return & $\begin{array}{l}\text { Monthly investor return given by the product of the daily relative changes in the value } \\
\text { of his or her portfolio after transaction costs and adjusting for portfolio in- and } \\
\text { outflows. For example, a monthly return of } 10 \% \text { takes the value } 0.1 \text { in the data. }\end{array}$ \\
\hline Std(Return) & $\begin{array}{l}\text { Investor-specific standard deviation of daily portfolio returns in a particular month (in } \\
\text { monthly terms). }\end{array}$ \\
\hline Return Expectation & $\begin{array}{l}\text { Reflects how optimistic a respondent is about his or her investment portfolio and its } \\
\text { returns in the upcoming month. Details on the survey questions are given in Table } 3 \text {. }\end{array}$ \\
\hline Risk Tolerance & $\begin{array}{l}\text { Reflects a respondent's general predisposition toward financial risk. Details on the } \\
\text { survey questions are given in Table } 3 \text {. }\end{array}$ \\
\hline Risk Perception & $\begin{array}{l}\text { Reflects a respondent's interpretation of how risky the stock market will be in the } \\
\text { upcoming month. Details on the survey questions are given in Table } 3 \text {. }\end{array}$ \\
\hline Confidence & $\begin{array}{l}\text { Reflects a respondent's confidence about the response to the return expectation } \\
\text { question. Details on the survey questions are given in Table } 3 \text {. }\end{array}$ \\
\hline
\end{tabular}

Because of data availability, the data retrieved from Statistics Netherlands refer to different years, that is, to 2007 for income and to 2008 for house value. 
Table 2

Descriptive Statistics

\begin{tabular}{|c|c|c|c|c|c|c|c|c|c|c|c|c|c|}
\hline \multirow[b]{2}{*}{ Month } & & \multicolumn{12}{|c|}{ Panel A: All Brokerage Accounts } \\
\hline & & Apr-08 & May-08 & Jun-08 & Jul-08 & Aug-08 & Sep-08 & Oct-08 & Nov-08 & Dec-08 & Jan-09 & Feb-09 & Mar-09 \\
\hline Investors & $\mathrm{N}$ & 1,376 & 1,376 & 1,376 & 1,376 & 1,376 & 1,376 & 1,376 & 1,376 & 1,376 & 1,376 & 1,376 & 1,376 \\
\hline Gender & mean & 0.08 & 0.08 & 0.08 & 0.08 & 0.08 & 0.08 & 0.08 & 0.08 & 0.08 & 0.08 & 0.08 & 0.08 \\
\hline \multirow{2}{*}{ Age } & mean & 50.56 & 50.56 & 50.56 & 50.56 & 50.56 & 50.56 & 50.56 & 50.56 & 50.56 & 50.56 & 50.56 & 50.56 \\
\hline & std & 13.57 & 13.57 & 13.57 & 13.57 & 13.57 & 13.57 & 13.57 & 13.57 & 13.57 & 13.57 & 13.57 & 13.57 \\
\hline \multirow[t]{2}{*}{ Account Tenure } & mean & 4.07 & 4.07 & 4.07 & 4.07 & 4.07 & 4.07 & 4.07 & 4.07 & 4.07 & 4.07 & 4.07 & 4.07 \\
\hline & std & 2.77 & 2.77 & 2.77 & 2.77 & 2.77 & 2.77 & 2.77 & 2.77 & 2.77 & 2.77 & 2.77 & 2.77 \\
\hline \multirow[t]{2}{*}{ Income $€$} & mean & 20,242 & 20,242 & 20,242 & 20,242 & 20,242 & 20,242 & 20,242 & 20,242 & 20,242 & 20,242 & 20,242 & 20,242 \\
\hline & std & 4,314 & 4,314 & 4,314 & 4,314 & 4,314 & 4,314 & 4,314 & 4,314 & 4,314 & 4,314 & 4,314 & 4,314 \\
\hline \multirow[t]{2}{*}{ Portfolio Value $€$} & mean & 52,854 & 52,695 & 44,872 & 42,840 & 45,963 & 37,688 & 31,127 & 30,100 & 30,679 & 29,564 & 26,514 & 27,875 \\
\hline & std & 156,058 & 156,096 & 134,883 & 127,338 & 135,203 & 117,935 & 101,325 & 104,663 & 105,279 & 99,322 & 91,598 & 92,307 \\
\hline \multirow[t]{2}{*}{ Fraction of Account Inv. } & mean & 0.68 & 0.67 & 0.63 & 0.64 & 0.65 & 0.63 & 0.63 & 0.64 & 0.64 & 0.64 & 0.64 & 0.65 \\
\hline & std & 0.31 & 0.31 & 0.32 & 0.32 & 0.32 & 0.32 & 0.33 & 0.33 & 0.33 & 0.33 & 0.34 & 0.33 \\
\hline \multirow[t]{2}{*}{ House Value $€$} & mean & 278,982 & 278,982 & 278,982 & 278,982 & 278,982 & 278,982 & 278,982 & 278,982 & 278,982 & 278,982 & 278,982 & 278,982 \\
\hline & std & 112,278 & 112,278 & 112,278 & 112,278 & 112,278 & 112,278 & 112,278 & 112,278 & 112,278 & 112,278 & 112,278 & 112,278 \\
\hline Derivatives & mean & 0.22 & 0.20 & 0.21 & 0.21 & 0.19 & 0.22 & 0.25 & 0.18 & 0.16 & 0.17 & 0.17 & 0.18 \\
\hline Traded & mean & 0.46 & 0.47 & 0.48 & 0.47 & 0.41 & 0.51 & 0.63 & 0.42 & 0.37 & 0.41 & 0.40 & 0.42 \\
\hline \multirow[t]{2}{*}{ Turnover (Traders) } & mean & 0.55 & 0.46 & 0.42 & 0.60 & 0.46 & 0.62 & 0.99 & 0.73 & 0.61 & 0.80 & 0.67 & 0.78 \\
\hline & std & 1.53 & 1.22 & 1.12 & 1.85 & 1.41 & 1.87 & 3.63 & 1.82 & 1.82 & 2.77 & 2.49 & 2.46 \\
\hline \multirow[t]{2}{*}{ Return } & mean & 0.03 & 0.00 & -0.17 & -0.10 & 0.05 & -0.24 & -0.23 & -0.12 & -0.04 & 0.00 & -0.16 & -0.01 \\
\hline & std & 0.16 & 0.13 & 0.19 & 0.19 & 0.17 & 0.19 & 0.33 & 0.19 & 0.20 & 0.19 & 0.18 & 0.19 \\
\hline \multirow[t]{2}{*}{ Std(Return) } & mean & 0.14 & 0.13 & 0.18 & 0.23 & 0.18 & 0.31 & 0.53 & 0.36 & 0.26 & 0.27 & 0.23 & 0.30 \\
\hline & std & 0.25 & 0.23 & 0.29 & 0.33 & 0.28 & 0.36 & 0.42 & 0.37 & 0.32 & 0.32 & 0.32 & 0.35 \\
\hline
\end{tabular}


Table 2

Descriptive Statistics - continued

\begin{tabular}{|c|c|c|c|c|c|c|c|c|c|c|c|c|c|}
\hline \multirow[b]{2}{*}{ Month } & & \multicolumn{12}{|c|}{ Panel B: Survey Respondents } \\
\hline & & Apr-08 & May-08 & Jun-08 & Jul-08 & Aug-08 & Sep-08 & Oct-08 & Nov-08 & Dec-08 & Jan-09 & Feb-09 & Mar-09 \\
\hline Investors & $\mathrm{N}$ & 787 & 701 & 605 & 557 & 520 & 491 & 650 & 402 & 330 & 312 & 272 & 291 \\
\hline Gender & mean & 0.07 & 0.08 & 0.08 & 0.08 & 0.08 & 0.08 & 0.09 & 0.08 & 0.08 & 0.08 & 0.09 & 0.09 \\
\hline \multirow[t]{2}{*}{ Age } & mean & 50.55 & 51.22 & 51.50 & 51.83 & 52.79 & 52.60 & 51.50 & 52.31 & 52.65 & 52.64 & 53.83 & 53.25 \\
\hline & std & 13.51 & 13.55 & 13.43 & 13.57 & 12.90 & 13.05 & 13.29 & 13.25 & 12.88 & 12.86 & 12.62 & 12.67 \\
\hline \multirow[t]{2}{*}{ Account Tenure } & mean & 3.93 & 3.98 & 4.09 & 3.98 & 4.11 & 4.08 & 4.26 & 4.35 & 4.34 & 4.45 & 4.53 & 4.38 \\
\hline & std & 2.76 & 2.79 & 2.77 & 2.78 & 2.77 & 2.76 & 2.78 & 2.73 & 2.75 & 2.74 & 2.68 & 2.71 \\
\hline \multirow[t]{2}{*}{ Income $€$} & mean & 20,181 & 20,088 & 20,109 & 19,978 & 20,085 & 20,002 & 20,147 & 19,892 & 19,859 & 20,046 & 20,034 & 20,028 \\
\hline & std & 4,285 & 3,956 & 4,240 & 3,729 & 3,835 & 4,153 & 4,197 & 3,808 & 3,543 & 3,897 & 3,844 & 3,860 \\
\hline \multirow[t]{2}{*}{ Portfolio Value $€$} & mean & 54,446 & 54,264 & 45,411 & 45,509 & 49,557 & 39,707 & 29,490 & 33,660 & 30,169 & 30,693 & 27,444 & 27,229 \\
\hline & std & 143,872 & 144,617 & 128,455 & 128,159 & 124,176 & 105,507 & 100,216 & 118,529 & 66,600 & 66,198 & 53,089 & 55,039 \\
\hline \multirow[t]{2}{*}{ Fraction of Account Inv. } & mean & 0.69 & 0.68 & 0.63 & 0.63 & 0.65 & 0.63 & 0.64 & 0.64 & 0.65 & 0.63 & 0.65 & 0.67 \\
\hline & std & 0.30 & 0.30 & 0.32 & 0.32 & 0.31 & 0.32 & 0.32 & 0.32 & 0.33 & 0.33 & 0.32 & 0.33 \\
\hline \multirow[t]{2}{*}{ House Value $€$} & mean & 276,690 & 272,969 & 272,038 & 273,559 & 274,221 & 274,736 & 277,543 & 272,429 & 272,020 & 273,443 & 277,193 & 273,037 \\
\hline & std & 110,125 & 102,015 & 109,290 & 101,943 & 101,006 & 110,771 & 112,864 & 104,787 & 98,530 & 99,506 & 108,672 & 100,576 \\
\hline Derivatives & mean & 0.24 & 0.23 & 0.25 & 0.25 & 0.23 & 0.24 & 0.26 & 0.19 & 0.20 & 0.24 & 0.22 & 0.20 \\
\hline Traded & mean & 0.52 & 0.54 & 0.55 & 0.52 & 0.46 & 0.54 & 0.64 & 0.46 & 0.42 & 0.48 & 0.49 & 0.45 \\
\hline \multirow[t]{2}{*}{ Turnover (Traders) } & mean & 0.65 & 0.43 & 0.49 & 0.57 & 0.36 & 0.50 & 1.10 & 0.86 & 0.47 & 0.56 & 0.70 & 1.00 \\
\hline & std & 1.82 & 1.13 & 1.41 & 1.61 & 0.91 & 1.08 & 4.68 & 2.23 & 1.51 & 1.07 & 2.08 & 3.91 \\
\hline \multirow[t]{2}{*}{ Return } & mean & 0.03 & 0.00 & -0.18 & -0.10 & 0.05 & -0.25 & -0.22 & -0.12 & -0.04 & 0.00 & -0.17 & -0.01 \\
\hline & std & 0.17 & 0.12 & 0.18 & 0.18 & 0.20 & 0.18 & 0.34 & 0.19 & 0.16 & 0.20 & 0.20 & 0.21 \\
\hline \multirow[t]{2}{*}{ Std(Return) } & mean & 0.15 & 0.13 & 0.18 & 0.23 & 0.18 & 0.31 & 0.53 & 0.37 & 0.26 & 0.28 & 0.25 & 0.32 \\
\hline & std & 0.29 & 0.22 & 0.29 & 0.34 & 0.30 & 0.38 & 0.43 & 0.39 & 0.32 & 0.31 & 0.38 & 0.43 \\
\hline \multirow[t]{2}{*}{ Return Expectation } & mean & 4.28 & 4.18 & 3.57 & 3.78 & 4.09 & 3.45 & 3.37 & 3.59 & 3.72 & 3.97 & 3.53 & 4.16 \\
\hline & std & 0.94 & 0.92 & 0.96 & 0.97 & 1.00 & 1.06 & 1.04 & 1.10 & 0.99 & 1.09 & 1.17 & 1.06 \\
\hline \multirow[t]{2}{*}{ Risk Perception } & mean & 4.49 & 4.44 & 5.00 & 4.15 & 3.97 & 4.45 & 4.27 & 4.26 & 4.24 & 4.18 & 4.44 & 4.24 \\
\hline & std & 1.63 & 1.58 & 1.93 & 1.13 & 1.15 & 1.17 & 1.31 & 1.28 & 1.24 & 1.22 & 1.32 & 1.20 \\
\hline \multirow[t]{2}{*}{ Risk Tolerance } & mean & 3.91 & 3.93 & 3.58 & 3.77 & 3.85 & 3.56 & 3.67 & 3.70 & 3.79 & 3.74 & 3.73 & 3.86 \\
\hline & std & 1.19 & 1.11 & 1.25 & 1.19 & 1.18 & 1.30 & 1.33 & 1.26 & 1.18 & 1.20 & 1.28 & 1.14 \\
\hline \multirow[t]{2}{*}{ Confidence } & mean & 5.31 & 5.35 & 5.45 & 5.48 & 5.40 & 5.58 & 5.62 & 5.48 & 5.42 & 5.32 & 5.51 & 5.38 \\
\hline & std & 0.96 & 0.96 & 0.94 & 0.99 & 1.07 & 1.00 & 0.97 & 1.04 & 1.03 & 1.06 & 0.98 & 1.04 \\
\hline
\end{tabular}

This table presents monthly summary statistics for the brokerage account data. Panel A refers to all investors for whom brokerage records are available. This sample includes investors who participated at least once in the survey during the sample period, and who were not excluded by the sample-selection restrictions defined in Section 3. The monthly summary statistics presented in Panel B refer to the subset of investors who responded to the survey in each respective month. Variables are defined in Table 1. Turnover statistics refer to the subset of investors that traded in a particular month. 
Table 3

\section{Survey Questions}

\begin{tabular}{ll}
\hline Survey Variable & \multicolumn{1}{c}{ Answer Categories } \\
\hline Return Expectation (1 = low/pessimistic, 7 = high/optimistic) & \\
$\begin{array}{l}\text { Next month, I expect my investments to do less well than desired. } \\
\text { For the next month, I have a positive feeling about my financial } \\
\text { future.* }\end{array}$ & 1 (totally agree) 7 (totally disagree) \\
$\begin{array}{l}\text { Next month, my investments will have a worse performance than } \\
\text { those of most other investors. }\end{array}$ & 1 (totally agree) 7 (totally disagree) \\
$\begin{array}{l}\text { Next month, it is unlikely that my investment behavior will lead to } \\
\text { positive returns. }\end{array}$ & 1 (totally agree) -7 (totally disagree) \\
For the next month, the future of my investment portfolio looks & 1 (totally agree) -7 (totally disagree) \\
good.* &
\end{tabular}

Risk Tolerance $(1=$ low risk tolerance, $7=$ high risk tolerance $)$

Next month, I prefer certainty over uncertainty when investing.

Next month, I avoid risks when investing.

Next month, I do not like to take financial risks.

1 (totally agree)-7 (totally disagree)

1 (totally agree)-7 (totally disagree)

1 (totally agree)-7 (totally disagree)

Next month, I do not like to "play it safe" when investing.* $\quad 1$ (totally agree)-7 (totally disagree)

Risk Perception ( 1 = low perceived risk, 7 = high perceived risk)

I consider investing to be very risky next month.*

I consider investing to be safe next month.

I consider investing to be dangerous next month.*

I consider investing to have little risk next month.

1 (totally agree)-7 (totally disagree)

1 (totally agree) -7 (totally disagree)

1 (totally agree)-7 (totally disagree)

1 (totally agree) -7 (totally disagree)

Confidence $(1=$ low confidence, 7 = high confidence $)$

How confident are you about this answer? ${ }^{\dagger}$

1 (not confident at all)-7 (very confident)

This table presents the questions used in this study's 12 monthly surveys. A 7-point Likert scale is used to record investors' response to each question. Each survey variable (return expectation, risk tolerance, risk perception, confidence) is calculated as the equally weighted average of the respective survey questions. $*$ denotes a reversescored question. ${ }^{\dagger}$ indicates that this question is asked five times, that is, after each return expectation question. 
Table 4

Impact of Past Return and Confidence on Changes in Return Expectation

\begin{tabular}{|c|c|c|c|c|c|c|c|c|c|c|}
\hline \multirow[t]{2}{*}{ Dependent Variable } & \multicolumn{2}{|c|}{$\Delta$ Return Expectation } & \multicolumn{2}{|c|}{ Return Expectation } & \multicolumn{2}{|c|}{$\begin{array}{c}\Delta \text { Return Expectation } \\
\text { (Baseline Spec.) } \\
\text { (3) }\end{array}$} & \multicolumn{2}{|c|}{$\begin{array}{c}\Delta \text { Return Expectation } \\
(4) \\
\end{array}$} & \multicolumn{2}{|c|}{$\begin{array}{l}\text { Return Expectation } \\
(5) \\
\end{array}$} \\
\hline & Coef. & Std. err. & Coef. & Std. err. & Coef. & Std. err. & Coef. & Std. err. & Coef. & Std. err. \\
\hline Return & 0.423 & $0.086 * * *$ & 0.411 & $0.078 * * *$ & -0.461 & 0.432 & -0.503 & 0.479 & 0.321 & 0.370 \\
\hline Confidence $\mathrm{t}-1$ & & & & & 0.032 & $0.014 * *$ & & & -0.021 & 0.022 \\
\hline Return*Confidence t-1 & & & & & 0.159 & $0.075 * *$ & & & 0.041 & 0.067 \\
\hline Avg. Confidence & & & & & & & -0.001 & 0.014 & & \\
\hline Return*Avg. Confidence & & & & & & & 0.166 & $0.086 *$ & & \\
\hline Gender & 0.054 & 0.039 & & & 0.053 & 0.040 & 0.060 & 0.040 & & \\
\hline Age & 0.000 & 0.001 & & & 0.000 & 0.001 & 0.001 & 0.001 & & \\
\hline Account Tenure & -0.002 & 0.003 & & & -0.002 & 0.003 & -0.002 & 0.003 & & \\
\hline $\ln ($ Income $)$ & 0.025 & 0.088 & & & 0.026 & 0.088 & 0.020 & 0.088 & & \\
\hline $\ln$ (Avg. Portfolio Value) & -0.003 & 0.006 & & & -0.003 & 0.006 & -0.003 & 0.006 & & \\
\hline $\ln ($ House Value $)$ & 0.013 & 0.045 & & & 0.012 & 0.045 & 0.014 & 0.045 & & \\
\hline Derivatives & 0.049 & 0.036 & 0.148 & $0.050 * * *$ & 0.052 & 0.036 & 0.049 & 0.036 & 0.136 & $0.057 * *$ \\
\hline Constant & -0.650 & 0.586 & 3.643 & $0.068 * * *$ & -0.067 & 0.590 & 0.151 & 0.601 & 3.837 & $0.156 * * *$ \\
\hline Time fixed effects & & YES & & YES & & YES & & YES & & YES \\
\hline Individual fixed effects & & NO & & YES & & NO & & NO & & YES \\
\hline N Observations & & 955 & & 918 & & 955 & & 955 & & ,955 \\
\hline $\mathrm{N}$ Investors & & ,045 & &, 376 & & ,045 & &, 045 & & ,045 \\
\hline $\mathrm{R}^{2}$ & & .164 & & .198 & & .165 & & .165 & & .200 \\
\hline
\end{tabular}

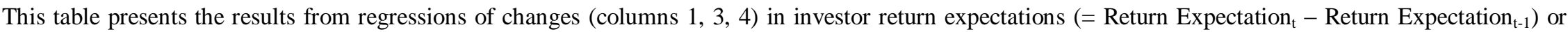
levels (columns 2,5) of return expectations (= Return Expectation ${ }_{t}$ ) on past investor returns, interactions of past returns with past confidence (columns 3 , 5) or with per investor average confidence (column 4), and a set of control variables. That is, we regress the end of the month update of return expectations in $t$ on the respective return experience during that month t. The columns show results of linear panel models. The number of individual investors included in the regression $(1,045)$ is smaller than the sample available for analysis $(1,376)$ because not all investors responded to the survey for two consecutive months (columns $1,3,4$, $5)$. Standard errors are clustered on the investor level. Variables are defined in Table $1 . *, * *$, and *** denote statistical significance at the $10 \%, 5 \%$, and $1 \%$ levels, respectively. 
Table 5

Impact of Confidence on Absolute Changes in Return Expectations

\begin{tabular}{|c|c|c|c|c|c|c|}
\hline \multirow[t]{2}{*}{ Dependent Variable } & \multicolumn{2}{|c|}{$\begin{array}{c}\mathrm{ABS}[\Delta \text { Return } \\
\text { Expectation] } \\
(1)\end{array}$} & \multicolumn{2}{|c|}{$\begin{array}{c}\mathrm{ABS}[\Delta \text { Return } \\
\text { Expectation] } \\
(2)\end{array}$} & \multicolumn{2}{|c|}{$\begin{array}{c}\ln (\mathrm{ABS}[\Delta \text { Return } \\
\text { Expectation] }) \\
(3)\end{array}$} \\
\hline & Coef. & Std. err. & Coef. & Std. err. & Coef. & Std. err. \\
\hline Return & -0.006 & 0.067 & 0.044 & 0.065 & 0.175 & 0.113 \\
\hline Confidence $\mathrm{t}-1$ & 0.092 & $0.012 * * *$ & 0.092 & $0.012 * * *$ & 0.119 & $0.021 * * *$ \\
\hline Std(Return) & & & 0.058 & 0.049 & 0.081 & 0.078 \\
\hline Gender & -0.033 & 0.040 & -0.032 & 0.040 & -0.013 & 0.071 \\
\hline Age & 0.002 & $0.001 * *$ & 0.002 & $0.001 * *$ & 0.002 & 0.002 \\
\hline Account Tenure & -0.005 & 0.005 & -0.005 & 0.005 & -0.006 & 0.008 \\
\hline $\ln ($ Income $)$ & 0.051 & 0.119 & 0.048 & 0.119 & -0.183 & 0.194 \\
\hline $\ln ($ Avg. Portfolio Value) & 0.011 & 0.008 & 0.013 & 0.008 & 0.004 & 0.013 \\
\hline $\ln ($ House Value $)$ & -0.008 & 0.057 & -0.008 & 0.057 & 0.075 & 0.099 \\
\hline Derivatives & 0.034 & 0.034 & 0.027 & 0.035 & 0.055 & 0.058 \\
\hline Constant & -0.370 & 0.804 & -0.377 & 0.803 & -0.700 & 1.250 \\
\hline Time fixed effects & \multicolumn{2}{|c|}{ YES } & \multicolumn{2}{|c|}{ YES } & \multicolumn{2}{|c|}{ YES } \\
\hline N Observations & \multicolumn{2}{|c|}{3,955} & \multicolumn{2}{|c|}{3,955} & \multicolumn{2}{|c|}{3,955} \\
\hline $\mathrm{N}$ Investors & \multicolumn{2}{|c|}{1,045} & \multicolumn{2}{|c|}{1,045} & \multicolumn{2}{|c|}{1,045} \\
\hline $\mathrm{R}^{2}$ & \multicolumn{2}{|c|}{0.046} & \multicolumn{2}{|c|}{0.047} & \multicolumn{2}{|c|}{0.030} \\
\hline
\end{tabular}

This table presents the results from regressions of absolute value (columns 1,2 ) or the $\log$ of the absolute value (column 3) of changes in investor return expectations (= ABS[Return Expectation $\mathrm{t}_{\mathrm{t}}-$ Return Expectation $\left.\left._{\mathrm{t}-1}\right]\right)$ on past confidence and a set of control variables. The columns show results of linear panel models. The number of individual investors included in the regression $(1,045)$ is smaller than the sample available for analysis $(1,376)$, because not all investors responded to the survey for two consecutive months. Standard errors are clustered on the investor level. Variables are defined in Table $1 . *, * *$, and $* * *$ denote statistical significance at the $10 \%, 5 \%$, and $1 \%$ levels, respectively. 
Table 6

Impact of Past Return Expectations on Risky Asset Demand

\begin{tabular}{lrc}
\hline Dependent Variable & \multicolumn{2}{c}{$\begin{array}{c}\text { Fraction of Account } \\
\text { Invested }\end{array}$} \\
\hline & Coef. & Std. err. \\
Return & 0.073 & $0.029 * *$ \\
Return Expectation t-1 & 0.014 & $0.006 * *$ \\
Risk Tolerance t-1 & -0.002 & 0.004 \\
Risk Perception t-1 & -0.004 & 0.003 \\
Derivatives & 0.027 & $0.013 * *$ \\
Constant & 0.519 & $0.155 * * *$ \\
Time fixed effects & \multicolumn{2}{c}{ YES } \\
Individual fixed effects & \multicolumn{2}{c}{ YES } \\
N Observations & \multicolumn{2}{c}{3,955} \\
N Investors & \multicolumn{2}{c}{1,045} \\
$\mathrm{R}^{2}$ & \multicolumn{2}{c}{0.038} \\
\hline
\end{tabular}

This table presents the results from regressions of the fraction of an investor's account value invested (=Portfolio Value / (Portfolio Value + Cash)) at the end of a particular month on return expectations at the beginning of the month (= Return Expectation ${ }_{t-1}$ ), and a set of control variables. The column shows results of a linear panel model. The number of individual investors included in the regression $(1,045)$ is smaller than the sample available for analysis $(1,376)$ because not all investors responded to the survey for two consecutive months (columns 1, 3, 4, 5). Standard errors are clustered on the investor level. Variables are defined in Table 1. *, **, and *** denote statistical significance at the $10 \%, 5 \%$, and $1 \%$ levels, respectively. 
Table 7

Impact of Absolute Changes in Return Expectations on Trading

\begin{tabular}{|c|c|c|c|c|c|c|c|c|}
\hline \multirow[t]{2}{*}{ Dependent Variable } & \multicolumn{2}{|c|}{$\begin{array}{l}\text { Turnover } \\
\text { (1) }\end{array}$} & \multicolumn{2}{|c|}{$\begin{array}{l}\text { Turnover } \\
\text { (2) }\end{array}$} & \multicolumn{2}{|c|}{$\begin{array}{c}\ln \text { (Turnover) } \\
\text { (3) }\end{array}$} & \multicolumn{2}{|c|}{$\begin{array}{c}\ln \text { (Number of Trades) } \\
\text { (4) }\end{array}$} \\
\hline & Coef. & Std. err. & Coef. & Std. err. & Coef. & Std. err. & Coef. & Std. err. \\
\hline Return $\mathrm{t}-1$ & -0.006 & 0.097 & -0.007 & 0.098 & 0.020 & 0.142 & 0.010 & 0.073 \\
\hline $\mathrm{ABS}[\Delta$ Return Expectation] $\mathrm{t}-1$ & 0.071 & $0.028 * *$ & 0.071 & $0.028 * *$ & 0.188 & $0.070 * * *$ & 0.085 & $0.049 *$ \\
\hline Risk Tolerance $\mathrm{t}-1$ & & & 0.030 & 0.024 & 0.056 & 0.050 & 0.051 & $0.029 *$ \\
\hline Risk Perception t-1 & & & 0.033 & $0.017 *$ & 0.056 & 0.040 & -0.008 & 0.023 \\
\hline Gender & -0.083 & 0.065 & -0.074 & 0.064 & -0.139 & 0.232 & 0.126 & 0.160 \\
\hline Age & 0.001 & 0.003 & 0.002 & 0.003 & 0.004 & 0.005 & 0.008 & $0.003 * *$ \\
\hline Account Tenure & 0.009 & 0.009 & 0.008 & 0.009 & 0.005 & 0.024 & -0.013 & 0.015 \\
\hline $\ln$ (Income) & 0.223 & 0.242 & 0.203 & 0.240 & 0.672 & 0.684 & 0.431 & 0.455 \\
\hline $\ln$ (Avg. Portfolio Value) & -0.083 & $0.023 * * *$ & -0.084 & $0.022 * * *$ & -0.222 & $0.043 * * *$ & 0.072 & $0.028 * *$ \\
\hline $\ln$ (House & -0.238 & $0.139 *$ & -0.226 & 0.139 & -0.622 & $0.352 *$ & -0.383 & $0.229 *$ \\
\hline Derivatives & 0.052 & 0.048 & 0.060 & 0.048 & -0.059 & 0.149 & 0.710 & $0.103 * * *$ \\
\hline Constant & 1.547 & 1.501 & 1.337 & 1.455 & -0.236 & 4.024 & 0.549 & 2.649 \\
\hline Time fixed effects & \multicolumn{2}{|c|}{ YES } & \multicolumn{2}{|c|}{ YES } & \multicolumn{2}{|c|}{ YES } & \multicolumn{2}{|c|}{ YES } \\
\hline N Observations & \multicolumn{2}{|c|}{$\begin{array}{c}1,369 \\
523\end{array}$} & \multicolumn{2}{|c|}{1,369} & \multicolumn{2}{|c|}{1,369} & \multicolumn{2}{|c|}{1,369} \\
\hline $\mathrm{N}$ Investors & \multirow{2}{*}{\multicolumn{2}{|c|}{$\begin{array}{c}523 \\
0.083\end{array}$}} & \multirow{2}{*}{\multicolumn{2}{|c|}{$\begin{array}{c}523 \\
0089\end{array}$}} & \multicolumn{2}{|c|}{523} & \multicolumn{2}{|c|}{523} \\
\hline $\mathrm{R}^{2}$ & & & & & \multicolumn{2}{|c|}{0.112} & \multicolumn{2}{|c|}{0.182} \\
\hline
\end{tabular}

This table presents the results from regressions of turnover (columns 1,2), the log of turnover (column 3), or the log of the number of transactions (column 4) in a particular month $t$ on the lagged absolute value of changes in investor return expectations $\left(=\mathrm{ABS}\left[\right.\right.$ Return Expectation $\mathrm{t}_{\mathrm{t}-1}-$ Return $\left.\left._{\text {Expectation }} \mathrm{t}_{-2}\right]\right)$ and a set of control variables. The columns show results of linear panel models. The number of individual investors included in the regression (523) is smaller than in the previous regressions $(1,045)$, because the sample refers to investors that traded in a particular month and because the use of lagged absolute changes in return expectation reduces the panel length. Standard errors are clustered on the investor level. Variables are defined in Table $1 . *, * *$, and *** denote statistical significance at the $10 \%, 5 \%$, and $1 \%$ levels, respectively. 
Table 8

Heterogeneity in Return Experiences and Changes in Return Expectations

\begin{tabular}{|c|c|c|c|c|c|c|c|c|c|c|c|c|c|}
\hline Month & & Apr-08 & May-08 & Jun-08 & Jul-08 & Aug-08 & Sep-08 & Oct- 08 & Nov-08 & Dec-08 & Jan-09 & Feb-09 & Mar-09 \\
\hline Return & mean & 0.03 & 0.00 & -0.18 & -0.10 & 0.05 & -0.25 & -0.22 & -0.12 & -0.04 & 0.00 & -0.17 & -0.01 \\
\hline Return & std & 0.17 & 0.12 & 0.18 & 0.18 & 0.20 & 0.18 & 0.34 & 0.19 & 0.16 & 0.20 & 0.20 & 0.21 \\
\hline Fraction Return $>=0$ & & 0.77 & 0.65 & 0.03 & 0.16 & 0.85 & 0.02 & 0.16 & 0.16 & 0.41 & 0.61 & 0.07 & 0.62 \\
\hline$\Delta$ Return Expectation & mean & & -0.11 & -0.60 & 0.20 & 0.32 & -0.65 & -0.08 & 0.22 & 0.13 & 0.25 & -0.43 & 0.63 \\
\hline$\Delta$ Return Expectation & $\mathrm{sd}$ & & 0.92 & 0.97 & 0.90 & 0.84 & 0.97 & 0.88 & 0.91 & 0.89 & 0.88 & 0.96 & 0.93 \\
\hline Fraction $\Delta$ Return Expectation & & & 0.47 & 0.23 & 0.56 & 0.67 & 0.23 & 0.38 & 0.61 & 0.50 & 0.60 & 0.31 & 0.72 \\
\hline $\mathrm{ABS}[\Delta$ Return Expectation] & mean & & 0.69 & 0.90 & 0.67 & 0.69 & 0.92 & 0.69 & 0.72 & 0.65 & 0.68 & 0.79 & 0.83 \\
\hline $\mathrm{ABS}[\Delta$ Return Expectation $]$ & sd & & 0.61 & 0.69 & 0.63 & 0.56 & 0.73 & 0.59 & 0.60 & 0.62 & 0.61 & 0.69 & 0.74 \\
\hline
\end{tabular}

This table presents monthly summary statistics for investor returns, changes in return expectations, and absolute changes in return expectations. Variables are defined in Table 1. 
Table 9

Impact of Past Return Expectations and Confidence on Return Performance

\begin{tabular}{|c|c|c|c|c|c|c|}
\hline \multirow[t]{2}{*}{ Dependent Variable } & \multicolumn{2}{|c|}{$\begin{array}{c}\text { Return } \\
\text { (1) }\end{array}$} & \multicolumn{2}{|c|}{$\begin{array}{l}\text { Return } \\
\text { (2) }\end{array}$} & \multicolumn{2}{|c|}{$\begin{array}{c}\text { Return } \\
\text { (3) }\end{array}$} \\
\hline & Coef. & Std. err. & Coef. & Std. err. & Coef. & Std. err. \\
\hline Return Expectation t- 1 & 0.003 & 0.003 & 0.012 & 0.017 & & \\
\hline Confidence t- 1 & & & 0.001 & 0.012 & -0.007 & $0.004 *$ \\
\hline Return Expectation $\mathrm{t}-1 *$ Confidence $\mathrm{t}-1$ & & & -0.002 & 0.003 & & \\
\hline Gender & 0.006 & 0.009 & 0.007 & 0.009 & 0.006 & 0.010 \\
\hline Age & 0.000 & 0.000 & 0.000 & 0.000 & 0.000 & 0.000 \\
\hline Account Tenure & 0.000 & 0.001 & 0.000 & 0.001 & 0.000 & 0.001 \\
\hline $\ln ($ Income $)$ & 0.000 & 0.028 & -0.002 & 0.028 & -0.009 & 0.029 \\
\hline $\ln ($ Avg. Portfolio Value $)$ & 0.016 & $0.003 * * *$ & 0.016 & $0.003 * * *$ & 0.017 & $0.003 * * *$ \\
\hline $\ln$ (House Value) & 0.010 & 0.016 & 0.010 & 0.016 & 0.012 & 0.017 \\
\hline Derivatives & -0.079 & $0.013 * * *$ & -0.079 & $0.013 * * *$ & -0.099 & $0.013 * * *$ \\
\hline Traded & -0.015 & $0.006 * *$ & -0.015 & $0.006 * *$ & & \\
\hline Turnover & -0.014 & $0.003 * * *$ & -0.014 & $0.003 * * *$ & & \\
\hline Constant & -0.365 & 0.230 & -0.361 & 0.233 & -0.296 & 0.238 \\
\hline Time fixed effects & \multicolumn{2}{|c|}{ YES } & \multicolumn{2}{|c|}{ YES } & \multicolumn{2}{|c|}{ YES } \\
\hline N Observations & \multicolumn{2}{|c|}{3,955} & \multicolumn{2}{|c|}{3,955} & \multicolumn{2}{|c|}{3,955} \\
\hline $\mathrm{N}$ Investors & \multicolumn{2}{|c|}{1,045} & \multicolumn{2}{|c|}{1,045} & \multicolumn{2}{|c|}{1,045} \\
\hline $\mathrm{R}^{2}$ & \multicolumn{2}{|c|}{0.323} & \multicolumn{2}{|c|}{0.324} & \multicolumn{2}{|c|}{0.295} \\
\hline
\end{tabular}

This table presents the results from regressions of investors' returns on past investor return expectations (column 1), continuous interactions of past returns with past confidence (column 2), past confidence (column 3), and a set of control variables. That is, we regress returns in a particular month $t$ on the respective expectations and confidence for that month which were elicited at the end of period $t-1$. The columns show results of linear panel models. The number of individual investors included in the regression $(1,045)$ is smaller than the sample available for analysis $(1,376)$, because not all investors responded to the survey for two consecutive months. Standard errors are clustered on the investor level. Variables are defined in Table 1. *,**, and *** denote statistical significance at the 10\%, 5\%, and $1 \%$ levels, respectively. 
Table 10

One-Month Transition Matrix Across Deciles of Confidence Distribution

\begin{tabular}{lcccccccccc}
\hline Decile t-1 & \multicolumn{10}{c}{ Decile t(Percentages) } \\
\hline & 1 & 2 & 3 & 4 & 5 & 6 & 7 & 8 & 9 & 10 \\
1 & 35.9 & 21.0 & 11.0 & 10.8 & 6.2 & 4.4 & 3.6 & 3.3 & 2.6 & 1.3 \\
2 & 18.6 & 25.0 & 21.0 & 12.2 & 9.0 & 5.9 & 2.9 & 2.7 & 1.9 & 0.8 \\
3 & 14.4 & 18.5 & 17.0 & 13.9 & 13.2 & 7.4 & 7.7 & 5.0 & 1.4 & 1.4 \\
4 & 6.9 & 12.0 & 17.4 & 18.9 & 14.0 & 12.5 & 8.9 & 5.9 & 1.8 & 1.8 \\
5 & 7.5 & 8.7 & 13.9 & 16.2 & 15.4 & 13.4 & 11.6 & 8.2 & 3.6 & 1.5 \\
6 & 4.2 & 3.2 & 11.0 & 11.7 & 14.9 & 21.1 & 13.9 & 9.7 & 6.2 & 4.0 \\
7 & 4.0 & 3.8 & 6.1 & 8.9 & 9.6 & 14.6 & 22.5 & 15.3 & 10.3 & 4.9 \\
8 & 1.3 & 3.2 & 4.2 & 5.0 & 7.9 & 11.6 & 20.2 & 20.2 & 17.9 & 8.7 \\
9 & 2.2 & 2.2 & 2.5 & 2.0 & 4.7 & 6.5 & 11.2 & 16.4 & 25.6 & 26.6 \\
10 & 1.7 & 1.2 & 1.7 & 1.7 & 1.7 & 1.9 & 5.5 & 6.9 & 24.9 & 52.9 \\
\hline
\end{tabular}

This table presents transition probabilities for an investor moving from a particular decile in the distribution of confidence at the end of the previous month to a decile in the corresponding distribution at the end of the current month. The confidence measure is defined in Table 1. 
Table 11

Impact of Past Returns on Confidence

\begin{tabular}{|c|c|c|c|c|c|c|c|c|c|c|}
\hline \multirow[t]{2}{*}{ Dependent Variable } & \multicolumn{2}{|c|}{$\begin{array}{c}\text { Confidence } \\
\text { (1) }\end{array}$} & \multicolumn{2}{|c|}{$\begin{array}{c}\text { Confidence } \\
\text { (2) }\end{array}$} & \multicolumn{2}{|c|}{$\begin{array}{c}\Delta \text { Confidence } \\
(3)\end{array}$} & \multicolumn{2}{|c|}{$\begin{array}{c}\text { Confidence } \\
(4)\end{array}$} & \multicolumn{2}{|c|}{$\begin{array}{c}\text { Confidence } \\
(5)\end{array}$} \\
\hline & Coef. & td. err. & Coef. & Std. err. & Coef. & Std. err. & Coef. & Std. err. & Coef. & td. err. \\
\hline Return & -0.337 & $0.072 * * *$ & -0.198 & $0.089 * *$ & -0.008 & 0.070 & -0.041 & 0.066 & -0.037 & 0.073 \\
\hline Return $>0$ & & & & & & & & & -0.004 & 0.028 \\
\hline Gender & 0.242 & $0.104 * *$ & 0.239 & $0.104 * *$ & 0.066 & $0.030 * *$ & & & & \\
\hline Age & 0.002 & 0.002 & 0.002 & 0.002 & 0.001 & 0.001 & & & & \\
\hline Account Tenure & -0.009 & 0.010 & -0.009 & 0.010 & -0.002 & 0.003 & & & & \\
\hline $\ln ($ Income $)$ & -0.228 & 0.226 & -0.219 & 0.226 & 0.090 & 0.083 & & & & \\
\hline $\ln$ (Avg. Portfolio Value) & 0.007 & 0.015 & 0.004 & 0.015 & -0.001 & 0.005 & & & & \\
\hline ln(House Value) & 0.095 & 0.115 & 0.089 & 0.116 & -0.047 & 0.041 & & & & \\
\hline Constant & 6.326 & $1.489 * * *$ & 6.311 & $1.490 * * *$ & -0.350 & 0.529 & 5.491 & $0.054 * * *$ & 5.492 & $0.054 * * *$ \\
\hline Time fixed effects & \multicolumn{2}{|c|}{$\mathrm{NO}$} & \multicolumn{2}{|c|}{ YES } & \multicolumn{2}{|c|}{ YES } & \multicolumn{2}{|c|}{ YES } & \multicolumn{2}{|c|}{ YES } \\
\hline Individual fixed effects & \multicolumn{2}{|c|}{$\mathrm{NO}$} & \multicolumn{2}{|c|}{ NO } & \multicolumn{2}{|c|}{ NO } & \multicolumn{2}{|c|}{ YES } & \multicolumn{2}{|c|}{ YES } \\
\hline N Observations & \multicolumn{2}{|c|}{5,918} & \multicolumn{2}{|c|}{5,918} & \multicolumn{2}{|c|}{3,955} & \multicolumn{2}{|c|}{5,918} & \multicolumn{2}{|c|}{5,918} \\
\hline $\mathrm{N}$ Investors & \multicolumn{2}{|c|}{1,376} & \multicolumn{2}{|c|}{1,376} & \multicolumn{2}{|c|}{1,045} & \multicolumn{2}{|c|}{1,376} & \multicolumn{2}{|c|}{1,376} \\
\hline $\mathrm{R}^{2}$ & \multicolumn{2}{|c|}{0.012} & \multicolumn{2}{|c|}{0.017} & \multicolumn{2}{|c|}{0.017} & \multicolumn{2}{|c|}{0.027} & \multicolumn{2}{|c|}{0.027} \\
\hline
\end{tabular}

This table presents the results from regressions of confidence at the end of a particular month (columns 1, 2, 4, 5) and changes in confidence (column 3 ) on past investor returns and a set of control variables. The columns show results of linear panel models. The number of individual investors included in the regression in column 3 (1,045) is smaller than the sample available for analysis $(1,376)$, because not all investors responded to the survey for two consecutive months. Standard errors are clustered on the investor level. Return $>0$ indicates whether the return in a particular month was positive (1) or not (0). Variables are defined in Table 1. * **, and $* * *$ denote statistical significance at the $10 \%, 5 \%$, and $1 \%$ levels, respectively. 
Table 12

\section{Relation between Confidence and Portfolio Risk}

\begin{tabular}{|c|c|c|}
\hline Dependent Variable & \multicolumn{2}{|c|}{ Std(Return) } \\
\hline & Coef. & Std. err. \\
\hline Confidence $\mathrm{t}-1$ & 0.015 & $0.007 * *$ \\
\hline Return Expectation t-1 & -0.003 & 0.008 \\
\hline Risk Perception t-1 & 0.014 & $0.004 * * *$ \\
\hline Risk Tolerance t- 1 & 0.023 & $0.007 * * *$ \\
\hline Gender & -0.024 & 0.024 \\
\hline Age & 0.000 & 0.001 \\
\hline Account Tenure & 0.008 & $0.003 * *$ \\
\hline $\ln$ (Income) & 0.048 & 0.059 \\
\hline $\ln$ (Avg. Portfolio Value) & -0.052 & $0.008 * * *$ \\
\hline $\ln ($ House Value) & -0.005 & 0.035 \\
\hline Derivatives & 0.208 & $0.029 * * *$ \\
\hline Constant & 0.187 & 0.403 \\
\hline Time fixed effects & \multicolumn{2}{|c|}{ YES } \\
\hline N Observations & \multicolumn{2}{|c|}{3,955} \\
\hline $\mathrm{N}$ Investors & \multicolumn{2}{|c|}{1,045} \\
\hline $\mathrm{R}^{2}$ & \multicolumn{2}{|c|}{0.277} \\
\hline
\end{tabular}

This table presents the results from the regression of investors' portfolio risk (standard deviation) on past investor confidence, beliefs and preferences, and a set of control variables. That is, we regress portfolio risk in a particular month $t$ on the respective expectations, risk tolerance, and confidence for that month which were elicited at the end of period t-1.The column shows results of a linear panel model. The number of individual investors included in the regression $(1,045)$ is smaller than the sample available for analysis $(1,376)$, because not all investors responded to the survey for two consecutive months. Standard errors are clustered on the investor level. Variables are defined in Table $1 . *, * *$, and $* * *$ denote statistical significance at the $10 \%, 5 \%$, and $1 \%$ levels, respectively. 


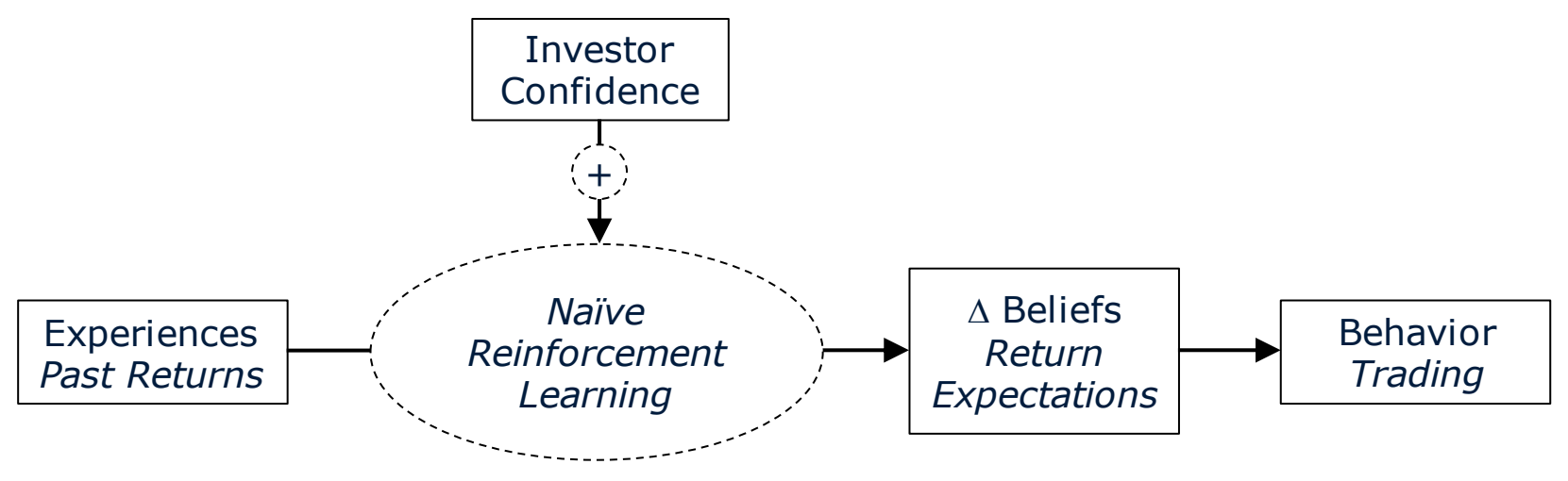

Figure 1. Theoretical Framework. 


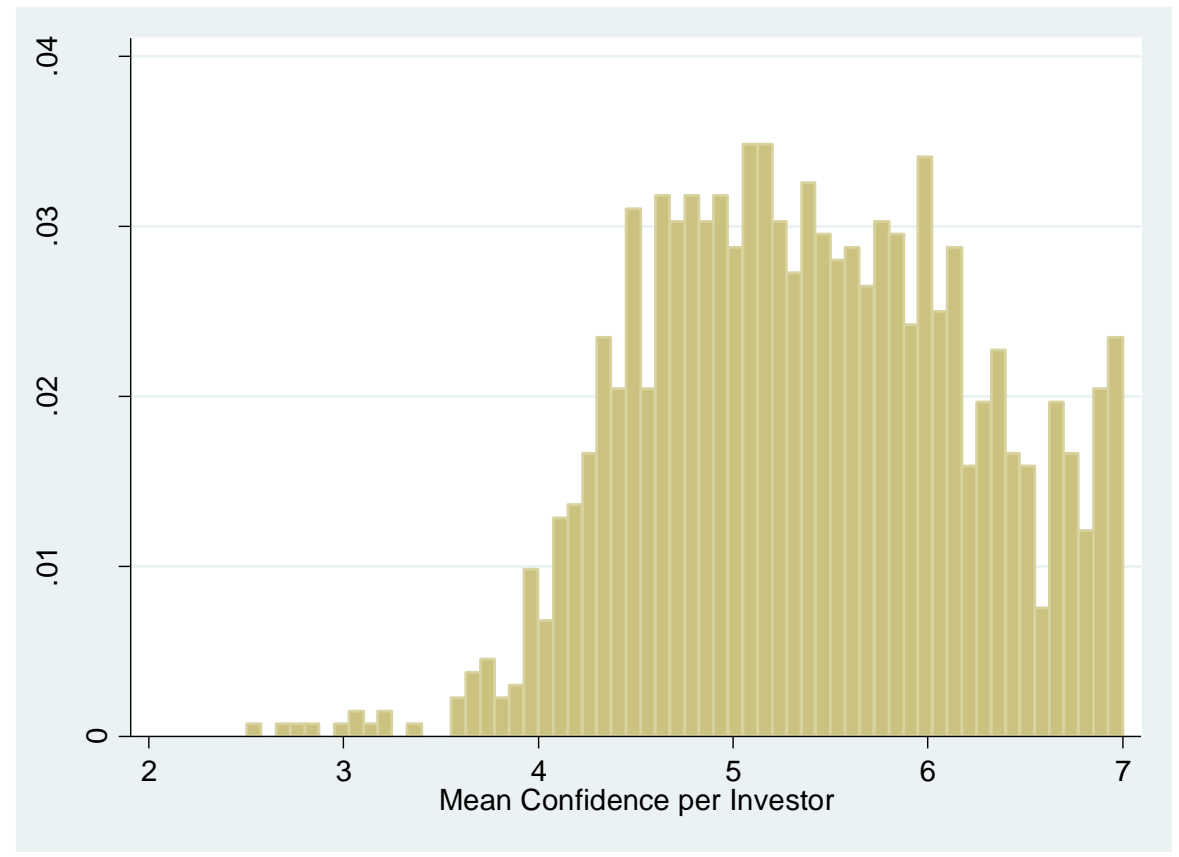

Figure 2. Distribution of Mean Investor Confidence. Mean confidence is the mean calculated over all observations per investor (time-series mean). Confidence is measured on a 7-point Likert scale (see Table 3). A small value indicates low confidence, whereas a large value indicates high confidence. 


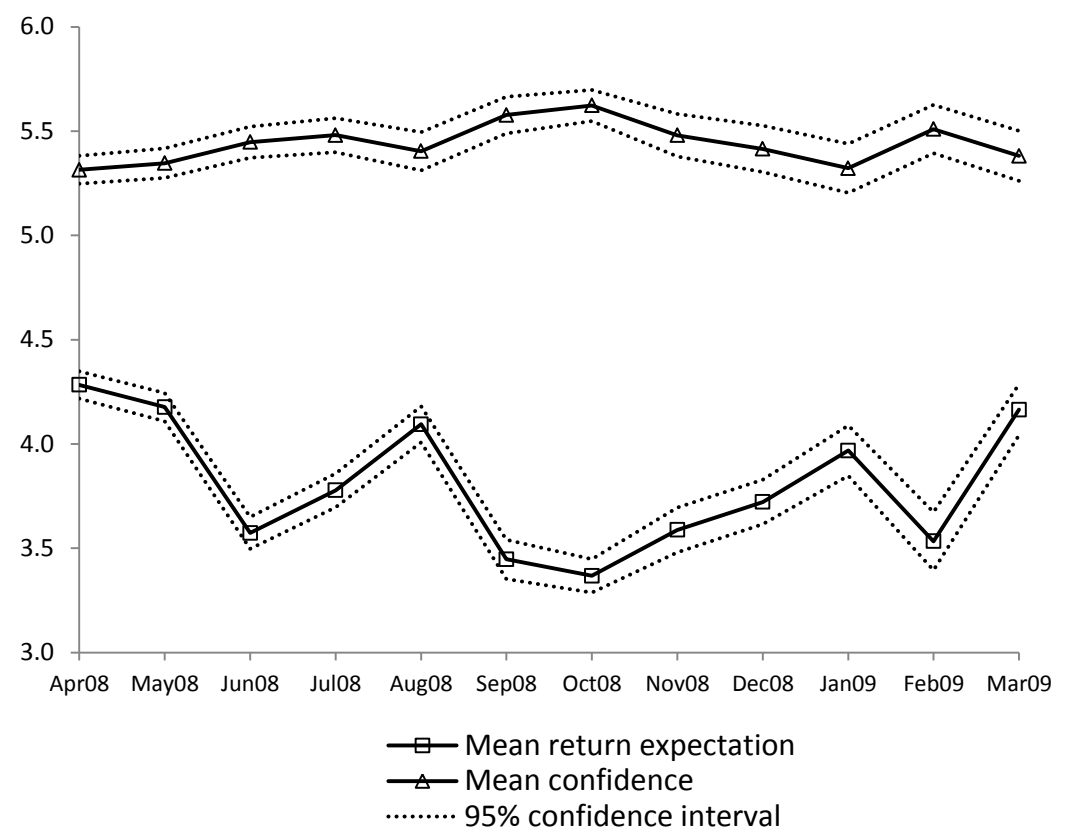

Figure 3. Investor Return Expectations and Confidence. Return expectations and confidence are measured on a 7-point Likert scale (see Table 3). A small value indicates low return expectations or confidence, whereas a large value indicates high return expectations or confidence. 


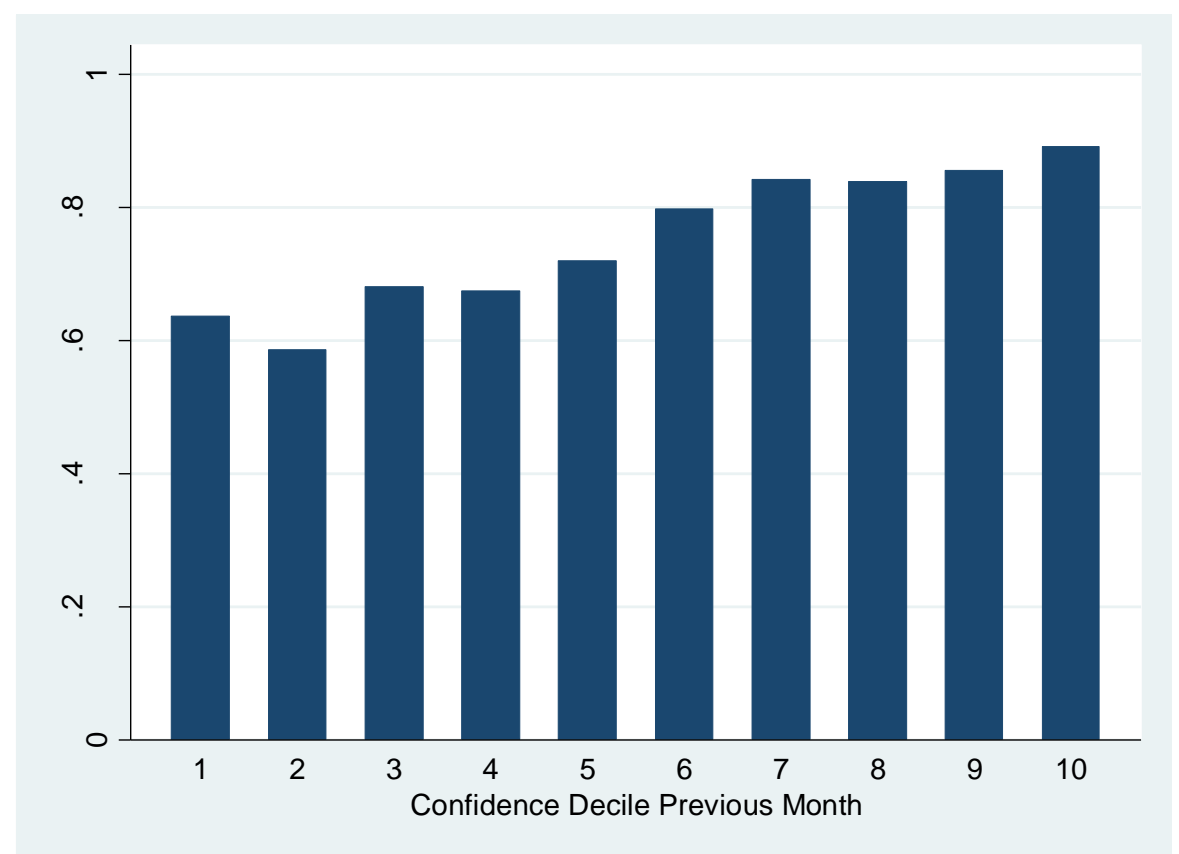

Figure 4. Mean of Absolute Changes in Return Expectations per Confidence Decile Previous Month. This figure shows the mean absolute change of investor return expectations (= mean of ABS[Return Expectation $_{t}-$ Return Expectation $\left.\mathrm{t}_{\mathrm{t}-1}\right]$ ) per decile of the distribution of confidence of the previous month. Return expectation and confidence are measured on a 7-point Likert scale (see Table 3). A small value indicates low return expectation or confidence, whereas a large value indicates high return expectation or confidence. 


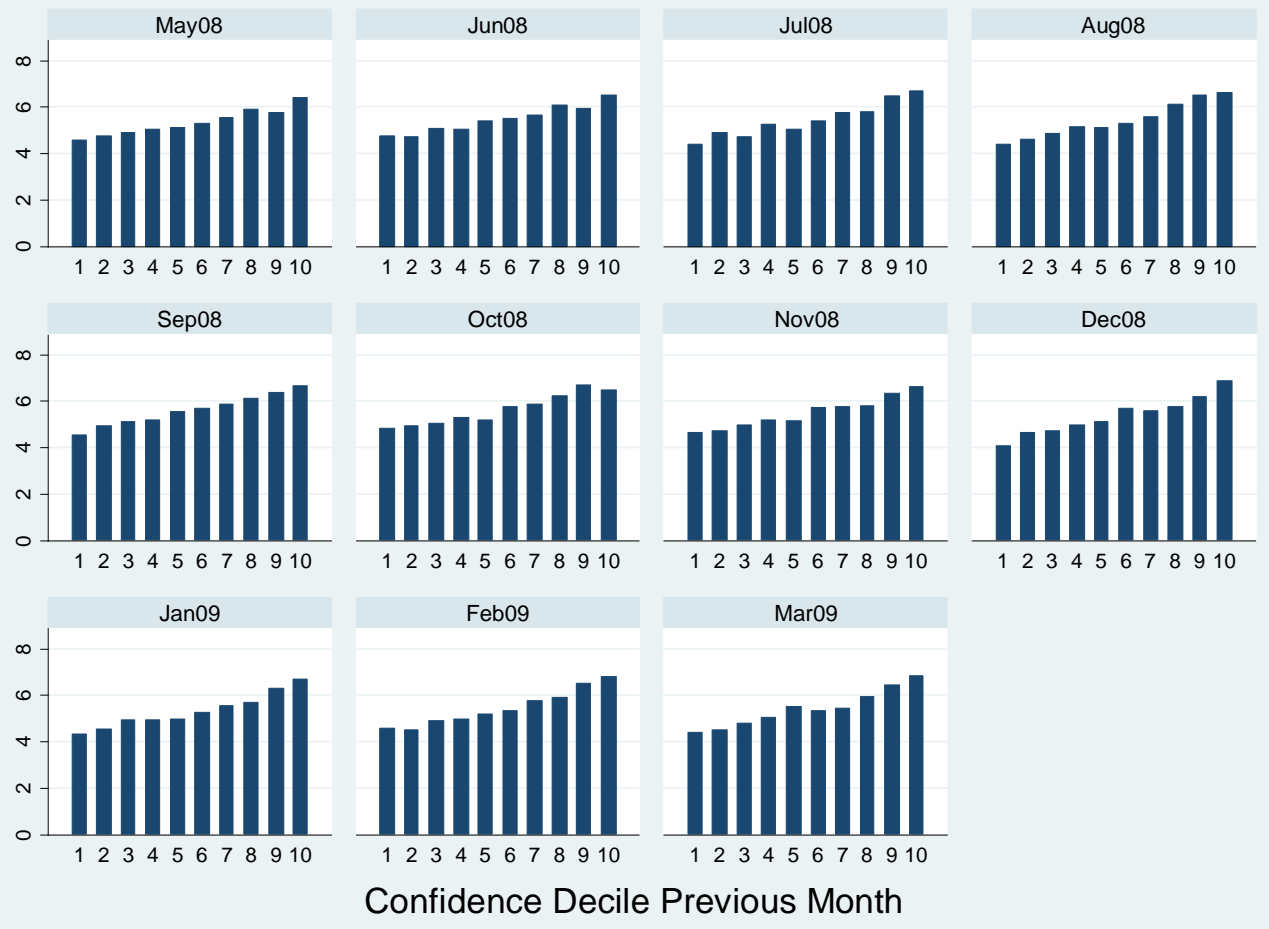

Figure 5. Mean of Investor Current Confidence per Confidence Decile Previous Month. This figure shows the mean confidence of investors at the end of a particular month per decile of the distribution of confidence of the previous month (cross-sectional mean). Confidence is measured on a 7-point Likert scale (see Table 3). A small value indicates low confidence, whereas a large value indicates high confidence. 